\title{
On several new or poorly-known Oriental Paradoxosomatidae (Diplopoda: Polydesmida), XXVII
}

\section{О несколыких новых или плохоизученных ориенталыных Paradoxosomatidae (Diplopoda: Polydesmida), XXVII}

\author{
Sergei I. Golovatch \\ С.И. Головач
}

Institute for Problems of Ecology and Evolution, Russian Academy of Sciences, Leninsky prospekt 33, Moscow 119071 Russia. E-mail: sgolovatch@yandex.ru

Институт проблем экологии и эволюции РАН, Ленинский проспект, 33, Москва 119071 Россия.

KEY WORDS: Diplopoda, Polydesmida, Paradoxosomatidae, taxonomy, new records, new genus, new species, Indonesia, Vietnam, China.

КЛЮЧЕВЫЕ СЛОВА: Diplopoda, Polydesmida, Paradoxosomatidae, таксономия, новые находки, новый род, новые вилы, Индонезия, Вьетнам, Китай.

ABSTRACT. This contribution is devoted to new records of eight known species, including three that are illustrated based on fresh material. A new genus and five new species are described: Margaritosoma novaeguineae sp.n. from western New Guinea, the easternmost representative of the basically Sunda genus Margaritosoma, as well as Tylopus nguyeni sp.n., Parasundanina faillei gen.n., sp.n., Hylomus srisonchaii sp.n. and $H$. propinquus sp.n., all from northern Vietnam. Parasundanina gen.n. differs from all nine presently known genera of the tribe Sundaninini except Arthrogonopus by the distinct, lateral, distofemoral sulcus on the gonopodal telopodite that delimits a postfemoral part, from Arthrogonopus, with six species endemic to Borneo, by the presence of a well-developed, ventral, postfemoral process, coupled with both laminae of the solenophore being rather evident and partly sheathing a long and flagelliform solenomere, with its tip exposed on the lateral side. The new genus also comprises $P$. medialis (Nguyen, 2010), comb.n. ex Sundanina Attems, 1914. Both Hylomus srisonchaii sp.n. and H. propinquus sp.n. seem to be troglobites that show conspicuous traits of troglomorphism.

How to cite this article: Golovatch S.I. 2019. On several new or poorly-known Oriental Paradoxosomatidae (Diplopoda: Polydesmida), XXVII // Arthropoda Selecta. Vol.28. No.4. P.459-478. doi: 10.15298/arthsel. 28.4.01

РЕЗЮМЕ. Данное сообщение посвящено новым находкам восьми известных видов, включая три, для которых по свежему материалу представлены иллюстрации. Описаны новый род и пять новых видов: Margaritosoma novaeguineae sp.n. из западной части Новой Гвинеи, пока самый восточный представитель в принципе зондского рода Margaritosoma, а также Tylopus nguyeni sp.n., Parasunda- nina faillei gen.n., sp.n., Hylomus srisonchaii sp.n. и H. propinquus sp.n., все из Северного Вьетнама. Parasundanina gen.n. отличается от всех девяти ныне известных родов трибы Sundaninini кроме Arthrogonopus наличием четкой боковой дистофеморальной бороздки на телоподите гонопода, которая выделяет постфеморальный участок, от Arthrogonopus с шестью видами-эндемиками Борнео присутствием развитого нижнего постфеморального отростка, а также тем, что обе пластины соленофора достаточно хорошо развиты и частично прикрывают длинный жгутиковидный соленомер, чей кончик виден сбоку. Новый род включает и P. medialis (Nguyen, 2010), comb.n. ex Sundanina Attems, 1914. И Hylomus srisonchaii sp.n., и Н. propinquus sp.n., видимо, троглобионты с явными чертами трогломорфизма.

\section{Introduction}

This paper is devoted to new records of several known, as well as to descriptions of a new genus and five new species of paradoxosomatid millipedes from Indonesia, Vietnam, Thailand and China.

\section{Material and methods}

The material is shared between the collections of the Institute of Ecology and Biological Resources (IEBR), Academy of Science and Technology, Hanoi, Vietnam, the Muséum national d'Histoire naturelle (MNHN), Paris, France, and the Zoological Museum, Moscow State University (ZMUM), Russia, as indicated in the text. Pictures were taken with a Canon EOS 5D digital camera and stacked using Zerene Stacker software. 

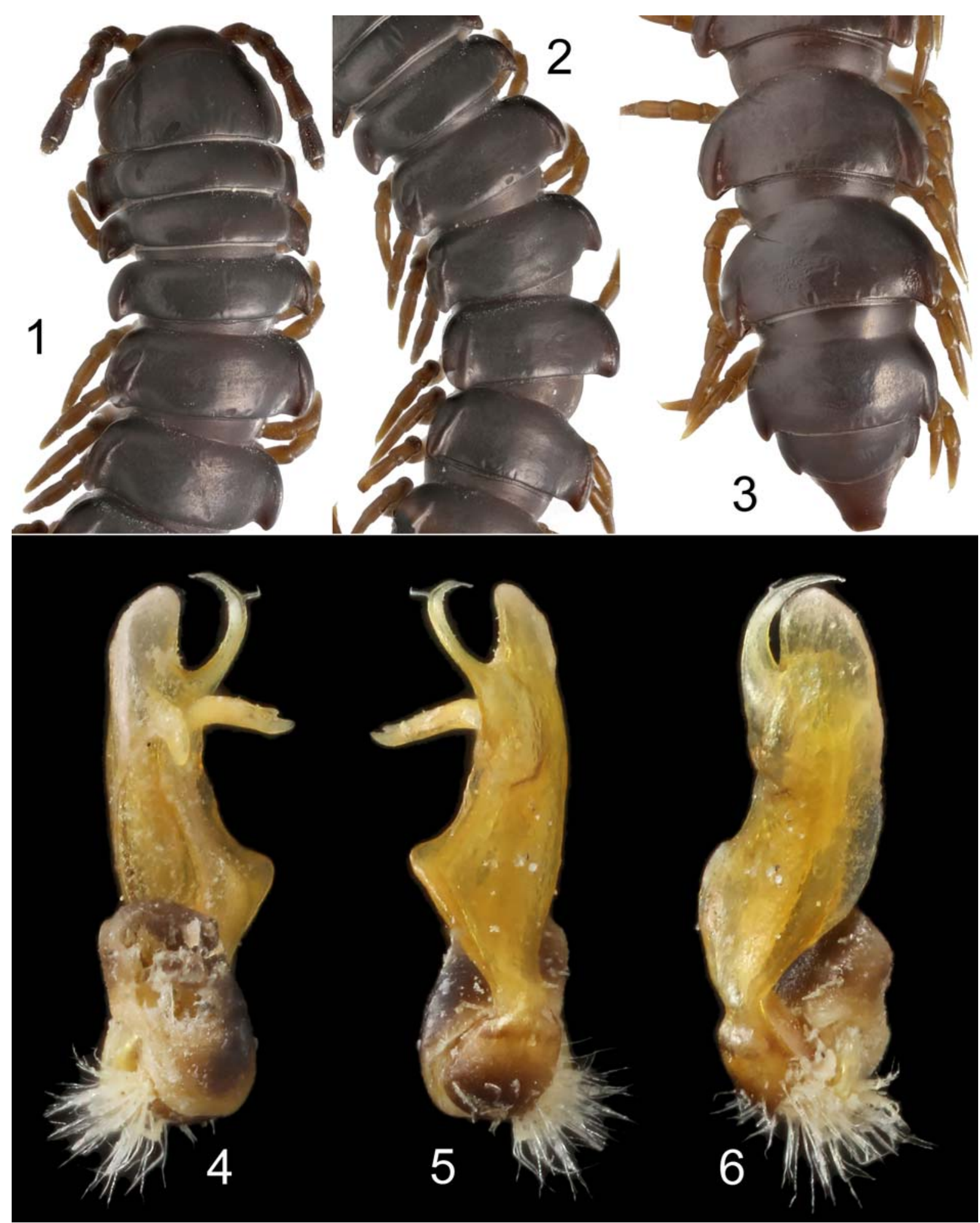

Figs 1-6. Aschistodesmus signatus (Attems, 1897), $0^{7}$ from near Fak-Fak: 1-3 - anterior, middle and posterior parts of body, respectively, dorsal view; 4-6 - right gonopod, dorsal, ventral and mesal views, respectively. Pictures by K. Makarov, not taken to scale.

Рис. 1-6. Aschistodesmus signatus (Attems, 1897), О7 из окрестностей Fak-Fak: 1-3 - соответственно передняя, средняя и задняя части тела, сверху; 4-6 - правый гонопод, соответственно сверху, снизу и изнутри. Фотографии К.В. Макарова, сняты без масштаба. 


\section{Taxonomic part}

\author{
Aschistodesmus signatus (Attems, 1897) \\ Figs 1-6.
}

MATERIAL. $2 \sigma^{7} \sigma^{7}, 1$ (ZMUM Rd 4497), E Indonesia, West Papua Prov., Onin Peninsula, 10 km E of Fak-Fak, Sakarteman River valley, S2 ${ }^{\circ} 56^{\prime} 54^{\prime \prime}, \mathrm{E} 132^{\circ} 22^{\prime} 23^{\prime \prime}, 100-300$ m a.s.l., primary tropical rainforest on limestone, 26.IX.2010, leg. M. Kalninš $3 \mathrm{O}^{7} \mathrm{O}^{7}$ (ZMUM Rd 4496), E Indonesia, West Papua Prov., Onin Peninsula, 5-7 km N of Fak-Fak, S2 ${ }^{\circ} 53^{\prime} 26^{\prime \prime}$, E132 $18^{\prime} 22^{\prime \prime}, 300$ $400 \mathrm{~m}$ a.s.l., primary lowland tropical rainforest on limestone, 23. IX.2010, leg. D. Telnov; 1 क (ZMUM Rd 4499), E Indonesia, West Papua Prov., S Bird's Neck Cape, $40 \mathrm{~km}$ E of Kaimana, Triton Bay, Lobo village and environs, $3^{\circ} 45^{\prime} 33^{\prime \prime}$, E134 $06^{\prime} 11^{\prime \prime}, 300-400$ $\mathrm{m}$ a.s.1., primeval lowland tropical rainforest on limestone, 1112.IX.2010, leg. D. Telnov.

REMARKS. This species is quite widespread in the western Papuan region: Halmahera, Great Kai, and western New Guinea [Golovatch, 2017]. The new samples are uniformly blackish brown to brown, devoid of mid-dorsal spots on metaterga (Figs 1-3), while the dorsoparabasal process of the gonopodal telopodite is shorter, not spiniform, but rounded (Figs 4-6). However, these variations seem to be so minor as to consider them only intraspecific.

Caloma agametum Chamberlin, 1945

MATERIAL. $1 \sigma^{7}$ (ZMUM Rd 4498), E Indonesia, West Papua Prov., S Bird's Neck Cape, $47 \mathrm{~km}$ E of Kaimana, Kamaka (former Warika), Triton Bay, near Lake Kamakawalar, S3 ${ }^{\circ} 45^{\prime} 33^{\prime \prime}$, E134 $23^{\prime} 05^{\prime \prime}, 90 \mathrm{~m}$ a.s.l., primeval tropical rainforest on limestone, 8.IX.2010, leg. M. Kalninš.

REMARK. This species seems to be endemic to New Guinea within both Indonesia and Papua New Guinea [Golovatch, Semenyuk, 2018].

Helicorthomorpha luzonensis (Peters, 1864)

MATERIAL. 1 o' (ZMUM Rd 4504), E Indonesia, West Papua Prov., Onin Peninsula, $10 \mathrm{~km}$ E of Fak-Fak, Sakarteman River valley, S2 ${ }^{\circ} 56^{\prime} 54^{\prime \prime}, \mathrm{E} 132^{\circ} 22^{\prime} 23^{\prime \prime}, 100-300 \mathrm{~m}$ a.s.1., primary tropical rainforest on limestone, 26.IX.2010, leg. M. Kalninš; 1 ( (ZMUM Rd 4505), E Indonesia, West Papua Prov., S Bird's Neck Cape, Kaimana, 35-40 km E of Triton Bay, Lengguru River valley, upstream of Oray village, $\mathrm{S} 3^{\circ} 43^{\prime} 26^{\prime \prime}$, E134 $06^{\prime} 06^{\prime \prime}$, 9-30 m a.s.1., primary lowland tropical rainforest on limestone, 13.IX.2010, leg. D. Telnov; $3 \bigcirc^{7} \sigma^{7}, 1$ ( (ZMUM Rd 4508), E Indonesia, West Papua Prov., S Bird's Neck Cape, 3-4 km E of Kaimana, S3 ${ }^{\circ} 39^{\prime} 26^{\prime \prime}$, E134 ${ }^{\circ} 46^{\prime} 21^{\prime \prime}, 150-200 \mathrm{~m}$ a.s.1., primary lowland tropical rainfores on limestone, 19-20.IX.2010, leg. D. Telnov; $1 \sigma^{7}, 1$ ( (ZMUM Rd 4506), E Indonesia, West Papua Prov., S Bird's Neck Cape, 47 km E of Kaimana, Triton Bay, Kamaka (former Warika) village, Lake Kamakawaka and surroundings, S3 ${ }^{\circ} 46^{\prime} 22^{\prime \prime}$, E1 $134^{\circ} 24^{\prime} 07^{\prime \prime}, 150$ $200 \mathrm{~m}$ a.s.l., primary lowland tropical rainforest on limestone, 27.IX.2010, D. Telnov; 2 ㅇ (ZMUM Rd 4507), E Indonesia, West Papua Prov., Onin Peninsula, 40-42 km NE of Fak-Fak, between Kokas and Goras villages, S2 ${ }^{\circ} 43^{\prime} 19^{\prime \prime}, \mathrm{E} 132^{\circ} 37^{\prime} 57^{\prime \prime}, 0-10 \mathrm{~m}$ a.s.1., primary tropical rainforest on limestone, 27.IX.2010, leg. D. Telnov.

REMARK. This widespread, obviously anthropochore species has hitherto been reported from the Philippines, Maluku Islands (Indonesia), New Guinea, Laos and southern China [Golovatch, 2018].

Inversispina erectispina Golovatch, 2012

MATERIAL. $20^{7} O^{7}$ (ZMUM Rd 4518), China, Yunnan Prov. $\mathrm{N}$ of Lijiang, $\mathrm{NW}$ of Baoshanxiang, $\mathrm{W}$ of Bengluo village, N27 $25^{\prime} 48^{\prime \prime}, \mathrm{E} 100^{\circ} 20^{\prime} 07^{\prime \prime}, 3580 \mathrm{~m}$ a.s.1., 23.V.2017, leg. I. Belousov \& I. Kabak.
REMARK. Known only from high in the mountains in Sichuan and Yunnan [Golovatch, 2016].

Nedyopus mahunkai (Korsós et Golovatch, 1989)

MATERIAL. $20^{7} \mathrm{O}^{7}, 6$ $+9,1$ juv. (ZMUM), Vietnam, $25 \mathrm{~km} \mathrm{E}$ of Hai Phong, Cat Ba Island National Park, ca. $10 \mathrm{~km} \mathrm{NW}$ of Cat Ba City, N20 $47^{\prime} 56^{\prime \prime}$, E106 $59^{\prime} 47^{\prime \prime}$, pitfall traps, 10-24.X.2011, leg. D. Fedorenko.

REMARK. A subsample of the same sample representing this species has already been recorded elsewhere [Golovatch, 2017].

Orthomorpha coarctata (de Saussure, 1860)

MATERIAL. $20^{7} \sigma^{7}$ (ZMUM Rd 4501), E Indonesia, Papua Prov., Biak Island, Cenderawasih Bay, ca. $34 \mathrm{~km}$ ENE of Biak, $\mathrm{S} 01^{\circ} 04^{\prime} 50^{\prime \prime}, \mathrm{E} 136^{\circ} 22^{\prime} 08^{\prime \prime}, 10-15 \mathrm{~m}$ a.s.l., primary lowland tropical rainforest, 22.III.2018, leg. D. Telnov; $10^{7}$ (ZMUM Rd 4502), E Indonesia, Papua Prov., central Biak Island, $16 \mathrm{~km} \mathrm{~W}$ of Biak, Urfu village, S0 $1^{\circ} 09^{\prime} 12^{\prime \prime}, \mathrm{E} 135^{\circ} 55^{\prime} 53^{\prime \prime}, 3-15 \mathrm{~m}$ a.s.l., tropical rainforest on coastal cliffs, 21.III.2018, leg. D. Telnov; 5 juv (ZMUM Rd 4503), Thailand, NW part of Phuket Island, S08 $00^{\prime} 16.7^{\prime \prime}$, E98 ${ }^{\circ} 17^{\prime} 52.0^{\prime \prime}$, sifted litter, 18.XI.2018, leg. Y. Marusik.

REMARK. This is a common, pantropical, anthropochore, "trump" species widespread also in the Papuan region, let alone across Thailand (e.g. Golovatch, Stoev [2009]. Likhitrakarn et al. [2011], Golovatch [2017]).

\section{Margaritosoma novaeguineae sp.n. Figs $7-15$.}

HOLOTYPE $\sigma^{7}$ (ZMUM Rd 4521), E Indonesia, West Papua Prov., southern Bird's Neck Cape, $47 \mathrm{~km}$ E of Kaimana, Triton Bay, near Kamaka (former Warika), S3 ${ }^{\circ} 46^{\prime} 24^{\prime \prime}$, E134 $10^{\circ} 28^{\prime \prime}, 100$ $\mathrm{m}$ a.s.l., gardens and secondary tropical rainforest on limestone, 10.IX.2010, leg. M. Kalninš.

PARATYPES: $1 \sigma^{7}$ (incomplete, lacking posterior part of body starting with segment 10), 2 ㅇ (1 $q$ incomplete, lacking posterior part of body starting with segment 9) (ZMUM Rd 4520), same place and date, together with holotype.

NAME. To emphasize the provenance from New Guinea.

DIAGNOSIS. Using Golovatch's [1996] key to all six presently known species of the Sunda genus Margaritosoma Jeekel, 1979, the new species keys out to M. sequens (Chamberlin. 1945), because both show transverse metatergal sulci and vestigial paraterga delimited by sulci on all segments [Chamberlin, 1945], but it differs from M. sequens and all other congeners by the characteristric shape of the gonopod, in particular the presence of a ventro-parabasal lobe (lo) on the femorite, the strong solenophore (sph) with an acuminate and laterad directed tip (a), and the digitiform, apically rounded, lateral branch (br) (Figs 10, 14, 15). In addition, the new species differs from $M$. sequens by the small size (8-9 vs. $13 \mathrm{~mm}$ ).

DESCRIPTION. Length ca. $9 \mathrm{~mm}$ ( $\sigma^{\top}$ holotype) or ca. 8 $\mathrm{mm}$ (complete 9 paratype), width of midbody pro- and metazonae 0.4 and $0.5 \mathrm{~mm}\left(\sigma^{7}\right.$ holotype) or 0.7 and $0.8 \mathrm{~mm}$ (complete + paratype), respectively. Coloration in alcohol uniformly dark brown with contrasting light yellowish to pallid antennomeres 6-8 and light brown to yellowish legs (Figs 7-10).

Body moniliform, with 20 segments. Head sparsely setose, especially its vertigial region; epicranial suture distinct (Fig. 10). Antennae long, slender and only slightly clavate (Figs 7-10), extending behind metatergum $3\left(\mathrm{O}^{7}\right)$ or $2(+)$ when stretched dorsally. In length, antennomere $2=3=4=$ $5=6>>1=7$. Interantennal isthmus about as wide as diameter of antennal socket (Fig. 10). Tegument shining, generally 


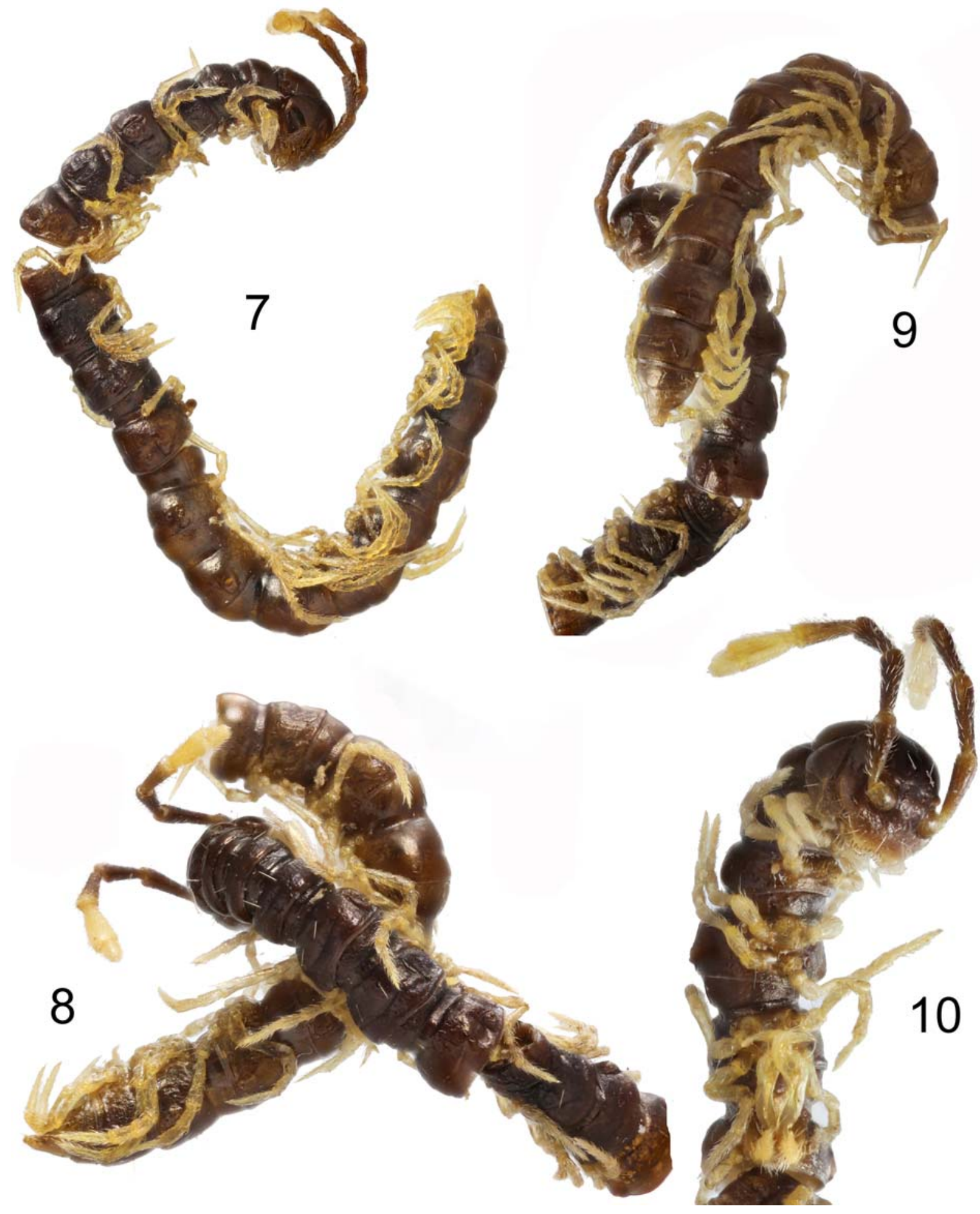

Figs 7-10. Margaritosoma novaeguineae sp.n., $0^{7}$ holotype. 7-9 - habitus, lateral, dorsal and lateral, and lateral and subdorsal views, respectively; 10 - anterior part of body together with gonopods, ventral view. Pictures by K. Makarov, not taken to scale.

Рис. 7-10. Margaritosoma novaeguineae sp.n., голотип О’. 7-9 - общий вид, соответственно сбоку, сверху и сбоку и сбоку и почти сверху; 10 - передняя часть тела с гоноподами, снизу. Фотографии К.В. Макарова, сняты без масштаба. 

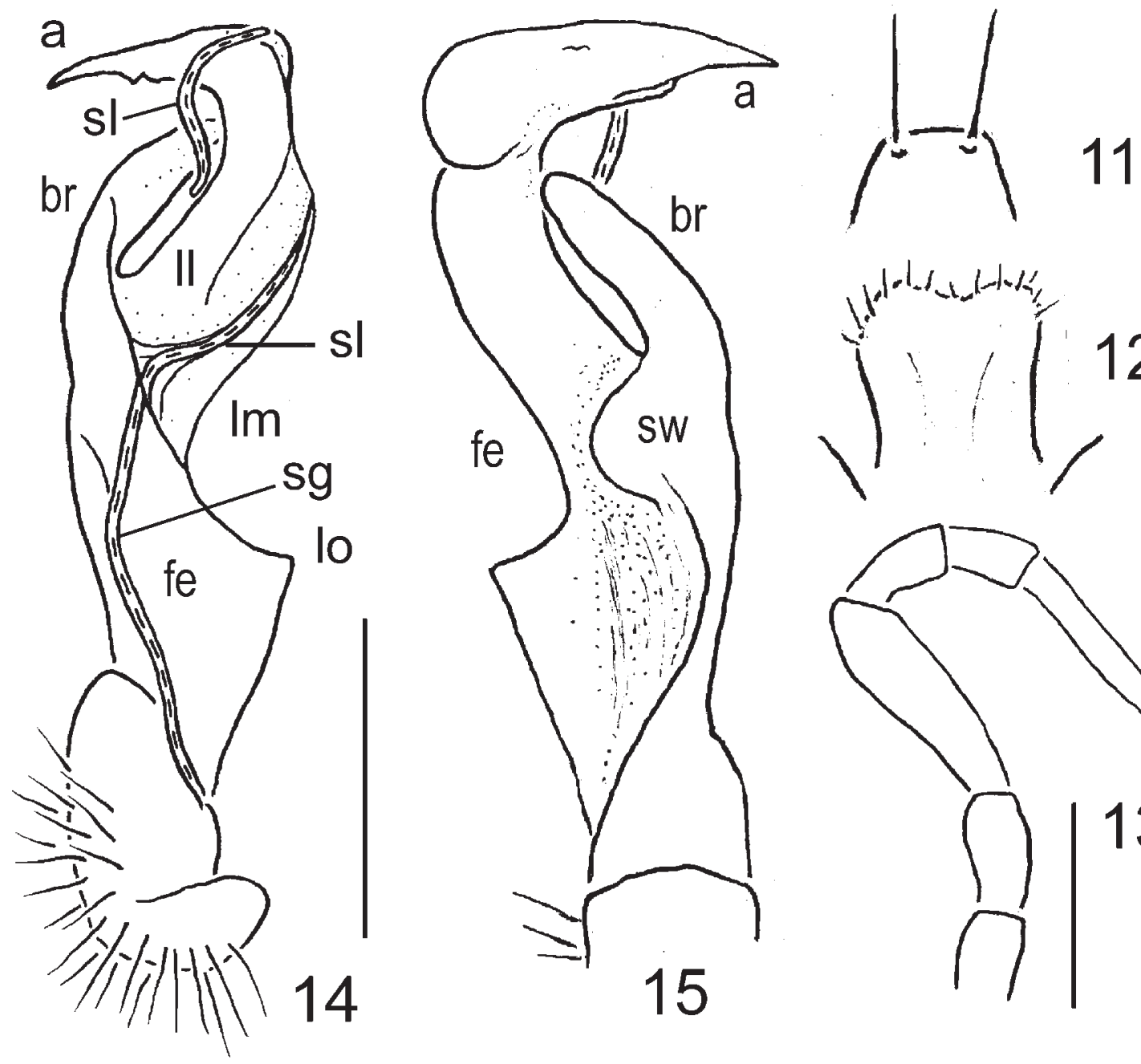

Figs 11-15. Margaritosoma novaeguineae sp.n., $\sigma^{7}$ holotype (11) and $\sigma^{7}$ paratype (12-15). 11 - hypoproct, ventral view; 12 sternal lobe between coxae 4, caudal view; 13 - leg 4, lateral view; 14-15 — right gonopod, ventral and dorsal views, respectively. Scale bars: $0.2 \mathrm{~mm}$. Designations explained in text.

Рис. 11-15. Margaritosoma novaeguineae sp.n., голотип О (11) и паратип Оج (12-15). 11 — гипопрокт, снизу; 12 - стернальная пластинка между тазиками 4, сзади; 13 - нога 4, сбоку; 14-15 - правый гонопод, соответственно снизу и сверху. Масштаб: 0,2 мм. Объяснения обозначений даны в тексте.

smooth, only in places finely rugulose, below paraterga microgranulate. In width, segment $2=3<$ collum $=$ segment $4<$ $5-16<$ head; body quickly tapering on segments $17-20$ (Figs 8-10). Paraterga vestigial, very poorly developed, small ridges set at about upper $1 / 3-1 / 2$ of midbody height, calluses thicker on pore-bearing segments than on poreless ones, delimited by a sulcus dorsally and another sulcus ventrally, both sulci being slightly abbreviated anteriorly; caudal corner always rounded, never drawn behind rear tergal margin, even paraterga 2 narrow arcuated ridges drawn neither anteriad nor caudad. Collum broadly and regularly rounded laterally. Tergal setae ca. 1/3 $\left(\sigma^{\top}\right)$ or ca. $1 / 4(+)$ as long as metatergum, setation pattern $2+2$ arranged in a transverse anterior (pre-sulcus) row. Ozopores small, slightly elevated above callus, placed near its caudal corner, lateral in position, invisible from above. Limbus entire. Stricture between pro- and metazona deep and broad, nearly smooth, at most faintly striolate. Transverse metatergal sulci unusually deep, simple, slightly arched medially, not reaching the bases of paraterga, present on segments 5-18. Axial line missing. Pleurosternal carinae nearly wanting, only on segment 2 represented by a small subtrangular crest. Epiproct (Figs 79) long, conical, tip faintly concave, lateral pre-apical papillae small. Hypoproct (Fig. 11) trapeziform, caudal margin with $1+1$ setae not borne on knobs.

Sterna sparsely setose, cross-impressions shallow, without modifications except for a high, transverse, linguiform, apically faintly concave, setose lobe between $\sigma^{\text {r }}$ coxae 4 (Figs 10, 12). No tubercles near gonopod aperture. Legs long and slender (Figs 7-10, 13), a little longer in $\sigma^{7}$, midbody ones ca. 1.5-1.6 $\left(\sigma^{7}\right)$ or 1.1-1.2 ( + ) times as long as body height, setose, neither adenostyles nor laterally swollen prefemora, nor ventral brushes.

Gonopods (Figs 10, 14, 15) rather simple and slender, in situ lying parallel to each other, only with tips directed laterad. Coxite about half as long as telopodite, subcylindrical, sparsely setose distoventrally; cannula as usual, a small, curved, hollow tube. Prefemoral (= densely setose) part ca. 
$1 / 3$ as long as acropodite and only slightly shorter than a medially hollow femorite (fe), the latter with a conspicuous, ventro-parabasal, subtriangular lobe (lo) and, a little more distally, a dorsal swelling (sw) at base of a distofemoral, finger-shaped, lateral branch (br). Seminal groove (sg) running along mesal face of fe, moving onto a long, flagelliform, free solenomere (sl) before base of br and lying squeezed between folds of a lamina lateralis (II) and a lamina medialis (lm) of solenophore (sph), both laminae being well-developed and sheathing most of sl; only tip of sl clearly exposed before a beak-shaped, acuminate, laterad directed sph tip (a). Both fe and sph separated by a distinct oblique fold/sulcus on ventral face.

REMARKS. The genus Margaritosoma Jeekel, 1979 has hitherto been known to comprise the following six described species: M. filum (Silvestri, 1895) (the type species), from Sumatra, Indonesia [Jeekel, 1979]; M. baliorum Golovatch, 1995, from Bali, Indonesia [Golovatch, 1995]; $M$. borneorum Golovatch, 1996, from Sabah, Malaysia and Brunei, Borneo [Golovatch, 1996]; M. nanum (Silvestri, 1895), from Enggano, Indonesia [Jeekel, 1979]; M. sequens (Chamberlin, 1945), from Java, Indonesia [Chamberlin, 1945; Jeekel, 1979; Golovatch, 1995]; and M. singaporense Golovatch, 1996, from Singapore. All of them have been keyed [Golovatch, 1996]. One more, still undescribed species has been recorded from Padang, Sumatra, Indonesia [Jeekel, 1979].

The finding of M. novaeguineae sp.n. in western New Guinea very considerably extends the known distribution range of Margaritosoma to the east, as the geographically closest congener, M. borneorum, is confined to Borneo. There can be no doubt whatever that more species of Margaritosoma are to be found and described in future at least across Indonesia.

\section{Tylopus kabaki Golovatch, 2014 Figs 16-32.}

MATERIAL. $2 \sigma^{7} \sigma^{7}$ (ZMUM Rd 4513), China, Yunnan Prov., NW of Lijiang, W of Chang Jiang (Yangtze River), NW of Jinzhua$\mathrm{ng}, 6 \mathrm{~km}$ of Tuozhi village, N27 $11^{\prime} 28^{\prime \prime}$, E99 $41^{\prime} 39^{\prime \prime}, 3710 \mathrm{~m}$ a.s.1., 18.V.2017; $10^{7}$ (ZMUM Rd 4510), China, Yunnan Prov., N of Lijiang, W of Maguwa, $4.2 \mathrm{~km} \mathrm{SE}$ of Shanggaohan village, $\mathrm{N} 27^{\circ} 26^{\prime} 33^{\prime \prime}, \mathrm{E} 100^{\circ} 19^{\prime} 27^{\prime \prime}, 4055 \mathrm{~m}$ a.s.1., 24.V.2017; $1 \mathrm{O}^{7}$ (ZMUM Rd 4512), China, Yunnan Prov., N of Lijiang, W of Maguwa, 4.4 $\mathrm{km}$ ENE of Shanggaohan village, N2 $7^{\circ} 28^{\prime} 25^{\prime \prime}, \mathrm{E} 100^{\circ} 20^{\prime} 29^{\prime \prime}, 3640$ $\mathrm{m}$ a.s.1., 25.V.2017; $3 \mathrm{\sigma}^{7} \sigma^{7}, 2$ क्+ (ZMUM Rd 4511), China, Yunnan Prov., Mekong Valley, ENE of Yezhixiang, $3 \mathrm{~km} \mathrm{NE}$ of Houqing, $\mathrm{N} 27^{\circ} 43^{\prime} 00^{\prime \prime}$, E99 $06^{\prime} 20^{\prime \prime}, 3615 \mathrm{~m}$ a.s.1., 29.V.2017, all leg. I. Belousov \& I. Kabak.

REMARKS. This high-montane species has hitherto remained known only from its original description from near Deqen, Yunnan, taken near and above the upper timberline at 3575-4025 $\mathrm{m}$ a.s.1. [Golovatch, 2014]. The above new samples are thus near-topotypes coming from about the same elevations in the same region.

Tylopus kabaki shows rather considerable variations, especially in body size. Thus, the near-topotypes are ca. 22$30 \mathrm{~mm}$ long, $2.0-2.4$ and $2.8-3.3 \mathrm{~mm}$ wide on midbody proand metaterga, respectively $\left(\sigma^{\top},+\right)$, vs. $21-23,1.9-2.3$ and 2.6-3.0 mm, respectively, in the types. In addition, $\sigma^{7} \sigma^{7}$ are usually blackish brown (Figs 16-19), whereas 00 are a little lighter, brown. Despite those minor variations, the gonopods (Figs 20-32) are sufficiently stable to make the species easily recognized through the characteristic, small, postfemoral, ventral peg (p), with its tip usually slightly enlarged and bent laterad, and a conspicuous, rounded, distodorsal lobe (lo) on a particularly strongly coiled and folded solenophore [Golovatch, 2014]. This is mainly the solenophore conformation that allows for this species to be assigned to Tylopus Jeekel, 1968 rather than Hedinomorpha Verhoeff, 1934. The latter genus is also quite large (18 species, see review and key in Golovatch [2019]) and confined to central, western and southwestern China, as well as Tajikistan, Central Asia. It so strongly resembles the former genus in somatic, leg and gonopodal structure that their close affinities are beyond doubt. However, the gonopods in Hedinomorpha spp. are usually not so complex compared to those of Tylopus spp., both genera share a simple gonopostfemoral lobe (I) and only a single gonopostfemoral outgrowth (h), while the solenophore is typically more slender and less strongly coiled. Because both genera co-occur, albeit probably never strictly sympatric, in the southwestern parts of China (at least Yunnan), these areas seem to mark the northern range limit of Tylopus and the southern one of Hedinomorpha.

\section{Tylopus nguyeni sp.n.} Figs 33-42.

HOLOTYPE $0^{7}$ (IEBR), Vietnam, Cao Bang Prov., Trà Linh District, Quoc Toan, Kyrang Cave, N22 $46^{\prime} 06.8^{\prime \prime}$, E106 $17^{\prime} 31.2^{\prime \prime}$, ca. $630 \mathrm{~m}$ a.s.1., 16.X.2018, leg. A. Faille, V.T. Tu, P.V. Phu.

NAME. Honours Nguyen Duc Anh, the leading specialist in diplopod taxonomy in Vietnam.

DIAGNOSIS. Using the latest key to all 62 then known Tylopus species [Likhitrakarn et al., 2016], including all 20 congeners hitherto described from Vietnam, 18 of which were also keyed [Nguyen, 2012], as well as considering another ten species described since [Golovatch et al., 2016; Golovatch, Semenyuk, 2018, Golovatch, 2018], T. nguyeni sp.n. keys out to couplet 40 . However, its metatergal sulci start with segment 5 , combined with the gonopod that shows a large postfemoral process $\mathbf{h}$ (Figs 37-39). In addition, the new species is distinguished among all congeners by the absence of a sternal lobe between $\sigma^{7}$ coxae 4 , among most congeners by the conspicuous, peg-shaped, gonopostefemoral process $\mathbf{z}$ (much like in the subcosmopolitan Oxidus gracilis (C.L. Koch, 1847)), coupled with the smooth tegument, the well-developed and mainly slightly upturned paraterga, the missing axial line, leg adenostyles, lateral bulges on $O^{7}$ prefemora etc.

DESCRIPTION. Length ca. $20 \mathrm{~mm}$, width of midbody pro- and metazonae 1.5 and $2.2 \mathrm{~mm}$, respectively $\left(\sigma^{7}\right)$. Coloration in alcohol generally castaneous brown, but clypeus, antennomeres $1-5$, paraterga, venter, legs, metatergal sulci, strictures between pro- and metazonae, and epiproct tip light yellowish grey, antennomeres 6 and 7 increasingly infuscate, $7^{\text {th }}$ dark brown, tip of antenna contrasting pallid (Figs 33-36). Caudal (post-sulcus) halves of metaterga usually slightly paler, light brown, than pre-sulcus halves.

Clypeolabral region densely, vertigial one sparsely, setose; epicranial suture fine, but distinct (Fig. 34). Antennae moderately long, slender and only slightly clavate (Fig. 33), extending behind metatergum 2 when stretched dorsally $\left(O^{7}\right)$. In length, antennomere $2=3=4=5=6>>1=7$. Interantennal isthmus almost as wide as diameter of antennal socket (Fig. 34). Tegument generally smooth and shining, only in places finely rugulose, below paraterga microgranulate. In width, head $<$ collum $<$ segment $3=4<2<5-16$; body gradually tapering thereafter (Figs 33. 34, 36). Paraterga well-developed, mostly wing-shaped, set at about upper $1 / 4$ of mid- 

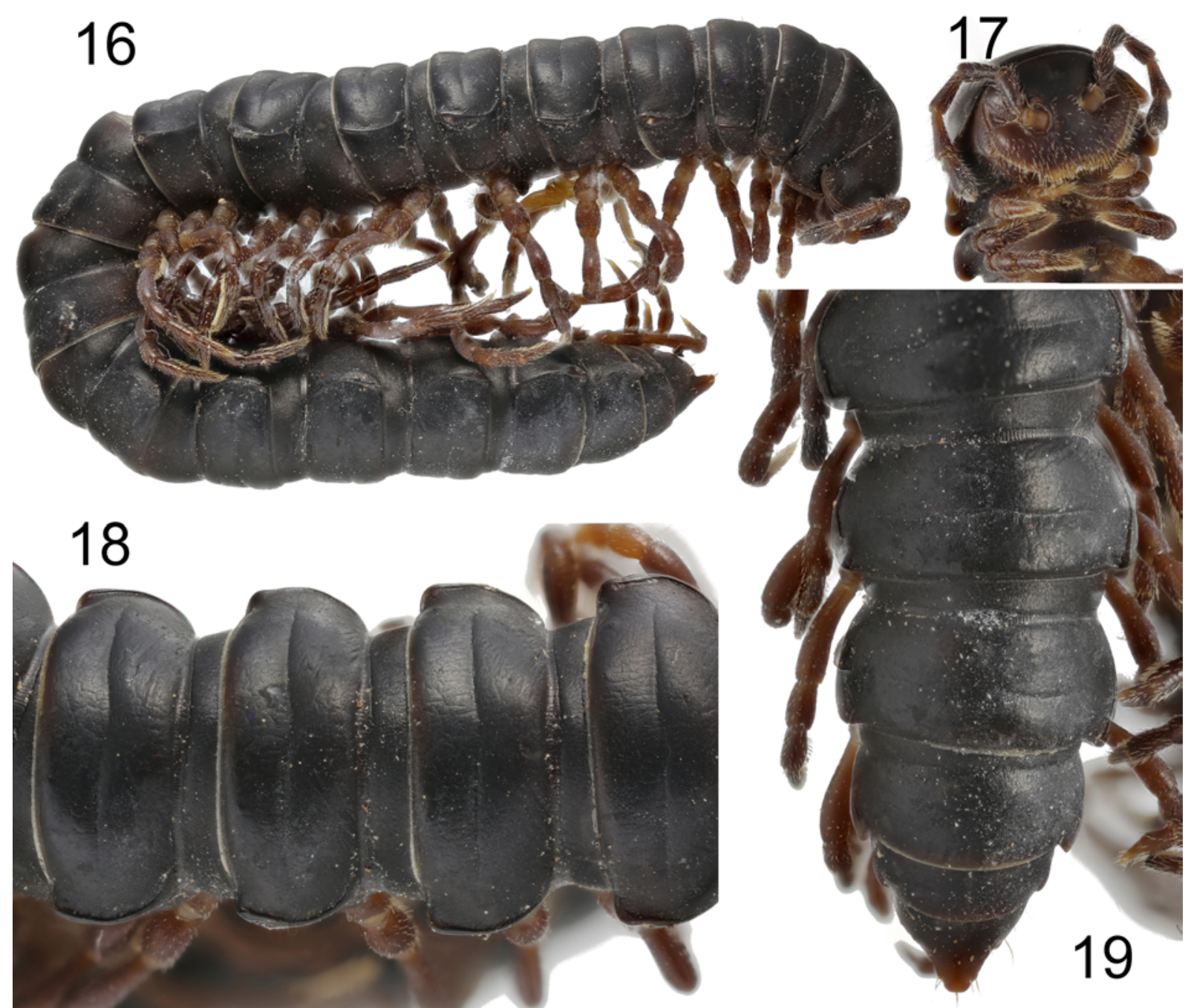

Figs 16-19. Tylopus kabaki Golovatch, 2014, $\sigma^{7}$ from near Shanggaohan: 16 - habitus, lateral view; 17 - anterior part of body, ventral view; 18 - midbody segments, dorsal view; 19 - posterior part of body, dorsal view. Pictures by K. Makarov, not taken to scale.

Рис. 16-19. Tylopus kabaki Golovatch, 2014, О7 из окрестностей Shanggaohan: 16 - общий вид, сбоку; 17 - передняя часть тела, снизу; 18 - среднетуловищные сегменты, сверху; 19 - задняя часть тела, сверху. Фотографии К.В. Макарова, сняты без масштаба.

body height, mostly slightly upturned and reaching the level of dorsum; calluses thin, in lateral view only a little thicker on pore-bearing segments than on poreless ones due to ozopores, delimited by a sulcus dorsally and another sulcus ventrally, both sulci being complete; paraterga on collum declined ventrolaterad less strongly than a very convex dorsum, clearly rounded even at an angulate caudal corner, lateral margin with two minute, apparently setigerous points; paraterga 2 set especially low, obviously drawn into rounded lappets both forward and caudad, with a distinct setigerous tooth in anterior $1 / 3$ and two apparently setigerous points at lateral margin; anterior margin of following paraterga a bordered shoulder only slightly bent caudolaterad, lateral edge almost straight, near anterior $1 / 3$ with a clear-cut, similarly setigerous tooth followed by one (pore-bearing segments) or two (poreless ones) similar, small, apparently also setiferous points; caudal corners of all postcollum paraterga increasingly well projecting behind caudal tergal margin, in segments 16-19 pointed and beak-shaped (Figs 33-36). Pore- bearing calluses faintly sinuous in caudal $1 / 3$, marking small and dorsally invisible ozopores; each latter lying inside an elongate groove at caudal $1 / 3$ of paraterga. Tergal setae mostly abraded, ca. $1 / 4-1 / 3$ as long as metatergum, setation pattern $1+1$ paramedian, arranged in a transverse anterior (pre-sulcus) row, regardless of $1+1$ often retained setae at anterolateral tooth of paraterga. Limbus entire. Stricture between pro- and metazonae deep and narrow, roughtly beaded at bottom. Transverse metatergal sulci deep, simple, slightly arched medially, not reaching the bases of paraterga, present on segments 5-18. Axial line missing. Pleurosternal carinae small, but evident, more or less arcuated, granular ridges with a caudal tooth, these increasingly reduced towards telson to disappear on segment 10. Epiproct (Fig. 36) long, conical, tip clearly emarginate, lateral pre-apical papillae small. Hypoproct (Fig. 40) subtrapeziform, caudal margin with $1+1$ setae borne on prominent knobs.

Sterna sparsely setose, cross-impressions shallow, without modifications except for two minute, paramedian, seti- 


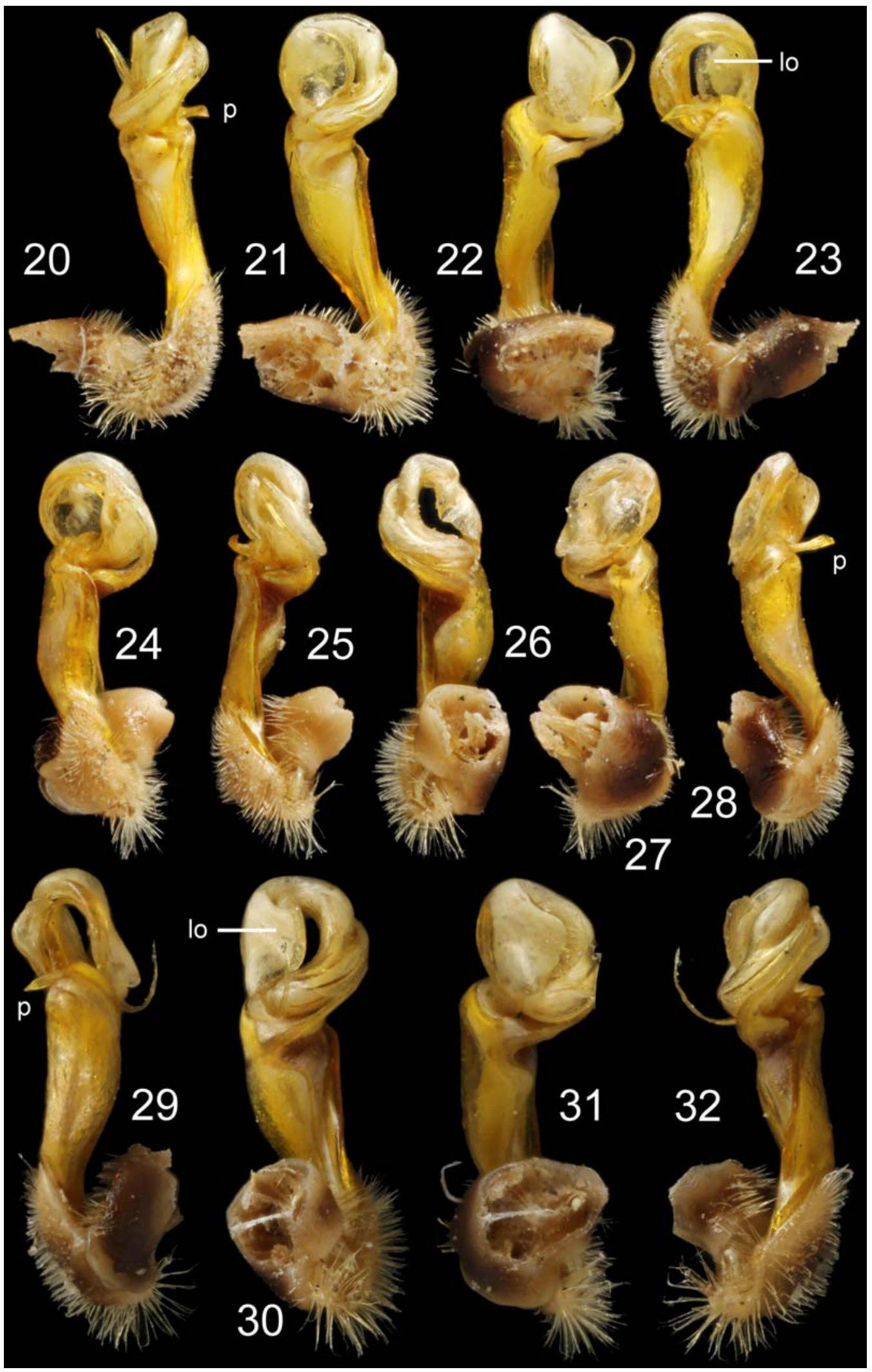

Figs 20-32. Gonopods of Tylopus kabaki Golovatch, 2014, ơ $0^{\top}$ from near Tuozhi (20-23), Houqing (24-28) and Shanggaohan (2932 ), various aspects. Pictures by K. Makarov, not taken to scale. Designations explained in text.

Рис. 20-32. Гоноподы Tylopus kabaki Golovatch, 2014, О О7 из окрестностей Tuozhi (20-23), Houqing (24-28) и Shanggaohan (29-32), разные аспекты. Фотографии К.В. Макарова, сняты без масштаба. Объяснения обозначений даны в тексте. 


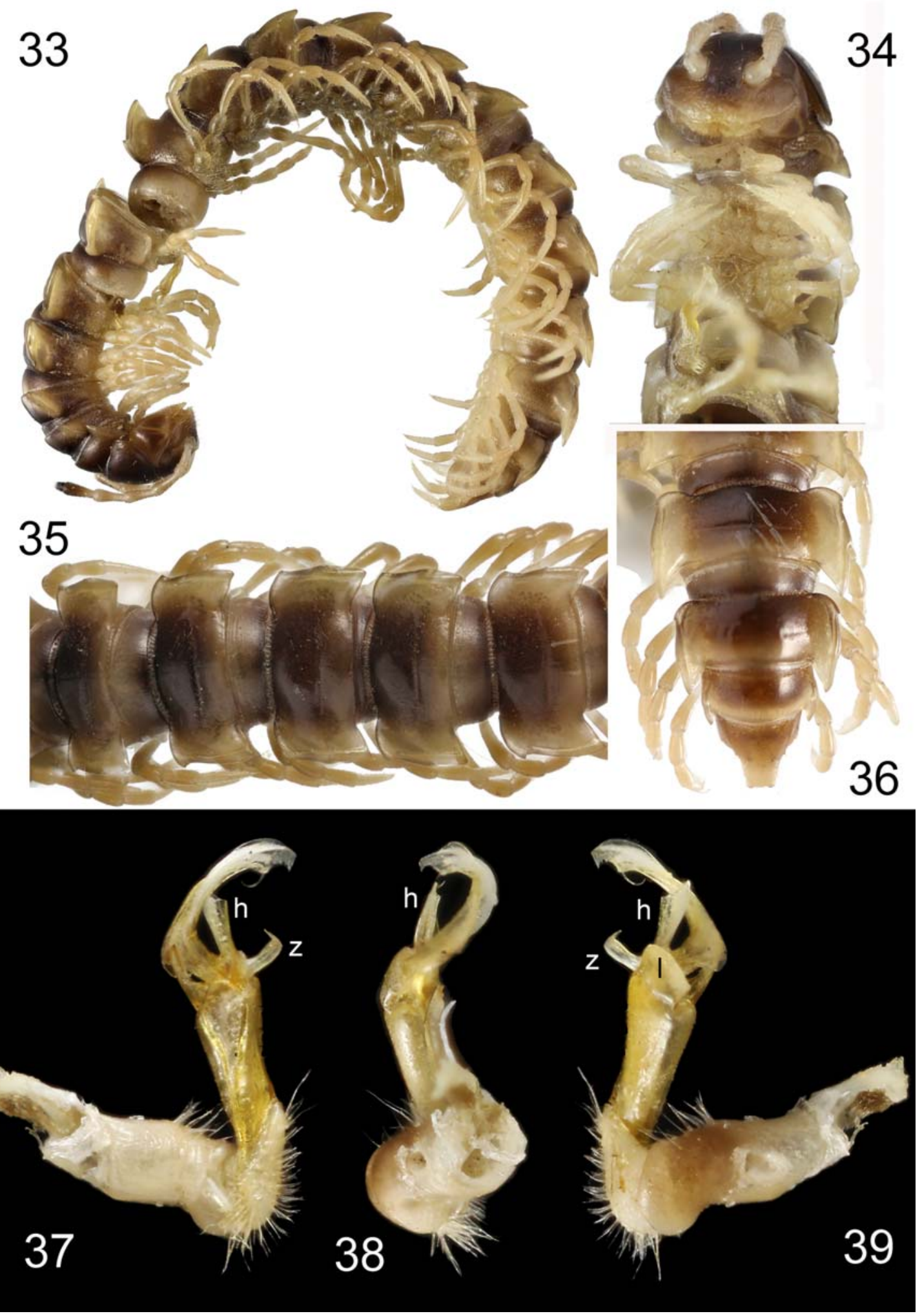

Figs 33-39. Tylopus nguyeni sp.n., O' holotype: 33 - habitus, lateral view; 34 - anterior part of body, ventral view; 35 - midbody segments, dorsal view; 36 - posterior part of body, dorsal view; 37-39 - left gonopod, mesal, dorsal and lateral views, respectively. Pictures by K. Makarov, not taken to scale. Designations explained in text.

Рис. 33-39. Tylopus nguyeni sp.n., голотип О': 33 - общий вид, сбоку; 34 - передняя часть тела, снизу; 35 - среднетуловищные сегменты, сверху; 36 - задняя часть тела, сверху; 37-39 - левый гонопод, соответственно изнутри, сверху и сбоку. Фотографии К.В. Макарова, сняты без масштаба. Объяснения обозначений даны в тексте. 


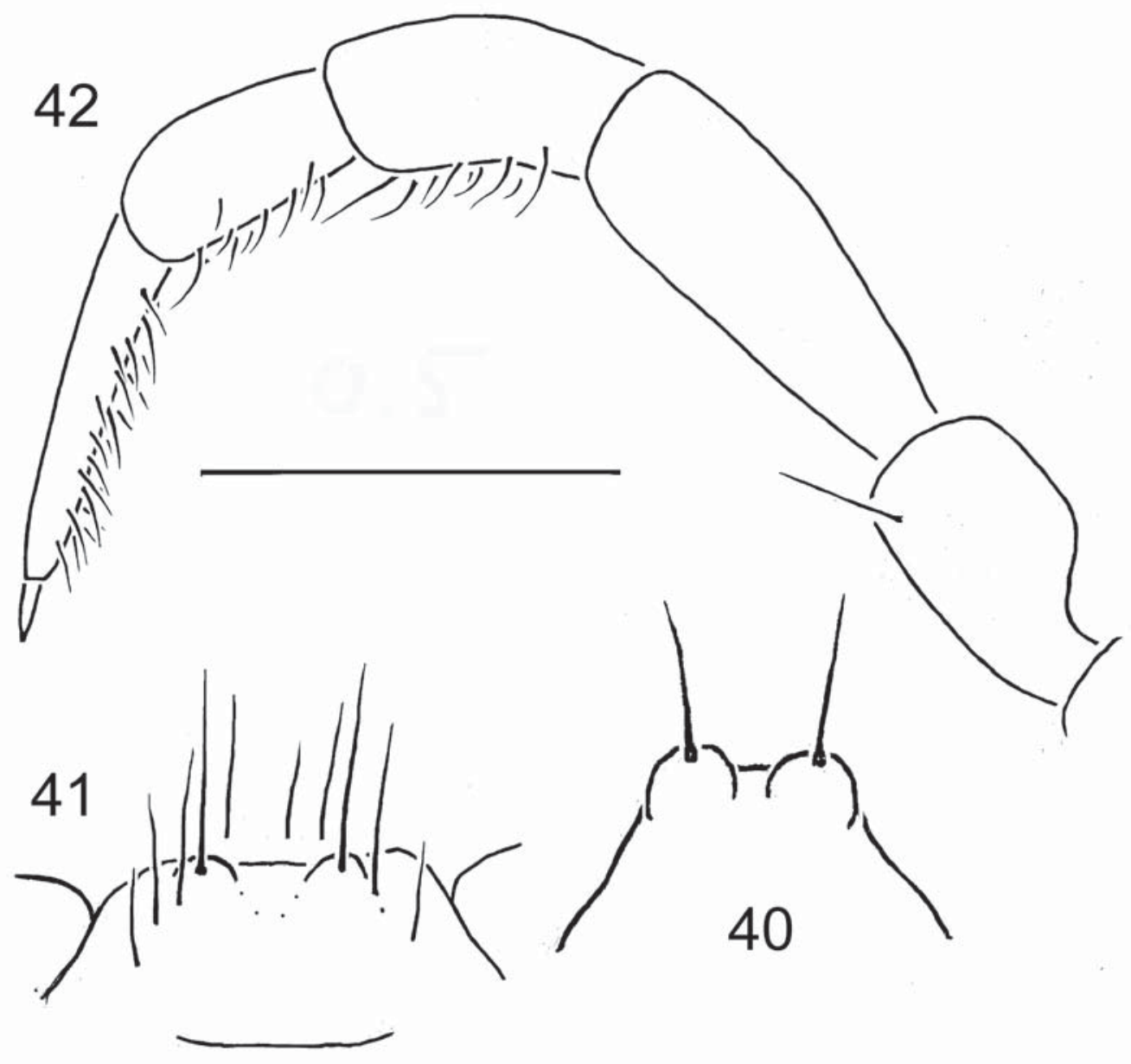

Figs 40-42. Tylopus nguyeni sp.n., $O^{7}$ holotype: 40 - hypoproct, ventral view; 41 - sternal structures between coxae 4 , caudal view; 42 - leg 9, lateral view. Scale bar: $0.5 \mathrm{~mm}$.

Рис. 40-42. Tylopus nguyeni sp.n., голотип О': 40 - гипопрокт, снизу; 41 - стернальные структуры между тазиками 4, сзади; 42 - нога 9, сбоку. Масштаб: 0,5 мм.

gerous, rounded knobs between $\sigma^{7}$ coxae 4 (Figs 34, 41). No tubercles near gonopod aperture. Legs rather long and slender (Figs 33, 42), apparently slightly incrassate compared to + , midbody ones ca. 1.5-1.6 $\left(O^{7}\right)$ times as long as body height, setose, neither adenostyles nor laterally swollen prefemora, nor ventral brushes.

Gonopods (Figs 37-39) relatively simple, in situ held parallel to each other, with tips directed laterad. Coxite subcylindrical, almost as long as femorite, setose distoventrally; cannula as usual, a small, curved, hollow tube. Prefemoral (= densely setose) part ca. $1 / 3$ as long as acropodite and only slightly shorter than a medially hollow femorite. Seminal groove running along mesal face of femorite, moving onto a long, flagelliform, free solenomere at base of a simple, rounded, subtriangular, postfemoral, lateral lobe (I) demarcated by a distinct, transverse, lateral sulcus to become squeezed between and sheathed by folds of a lamina lateralis and a lamina medialis of solenophore, both laminae being well-developed, long, moderately coiled; only tip of solenomere clearly exposed; postfemoral part bearing not only lobe 1, but also two distinct processes: a sharp, laterally curved, peg-shaped, ventral $\mathbf{z}$ and an erect, similarly long, flattened, apically triangular, lobe-shaped $\mathbf{h}$.
REMARK. With its 73 currently recognized species (and many more still to be expected in future) that range from southern China in the north, through most of Indochina, to Myanmar in the south, Tylopus remains the largest genus of Paradoxosomatidae globally, sharing only with further two genera of Sulciferini, i.e. Oxidus Cook, 1911 and some Hedinomorpha Verhoeff, 1934, a more or less distinctly separated apicolateral lobe (Fig. 39, I) of the postfemoral part of the gonopod [Golovatch, 2019].

\section{Hedinomorpha flavobulbus Golovatch, 2019} Figs 43-50.

MATERIAL. $3 \sigma^{7} \sigma^{7}$ (ZMUM Rd 4519), China, Gansu Prov., WWS of Longnan (Wudu), Yin Duoguosa \& Aounang divide, $33^{\circ} 21^{\prime} 14^{\prime \prime} \mathrm{N}, 104^{\circ} 29^{\prime} 45^{\prime \prime} \mathrm{E}, 3650 \mathrm{~m}$ a.s.l., 22.06.2017, leg. I. Belousov \& I. Kabak.

REMARKS. The above samples are strict topotypes, unfortunately misplaced and thus omitted from the original description [Golovatch, 2019]. The $\sigma^{7} \sigma^{7}$ are generally blackish, ca. 26-28 mm long, 2.4-2.5 and 2.8-3.0 mm wide on midbody pro- and metazonae, respectively. New illustrations (Figs 43-50) are provided to show slight individual 


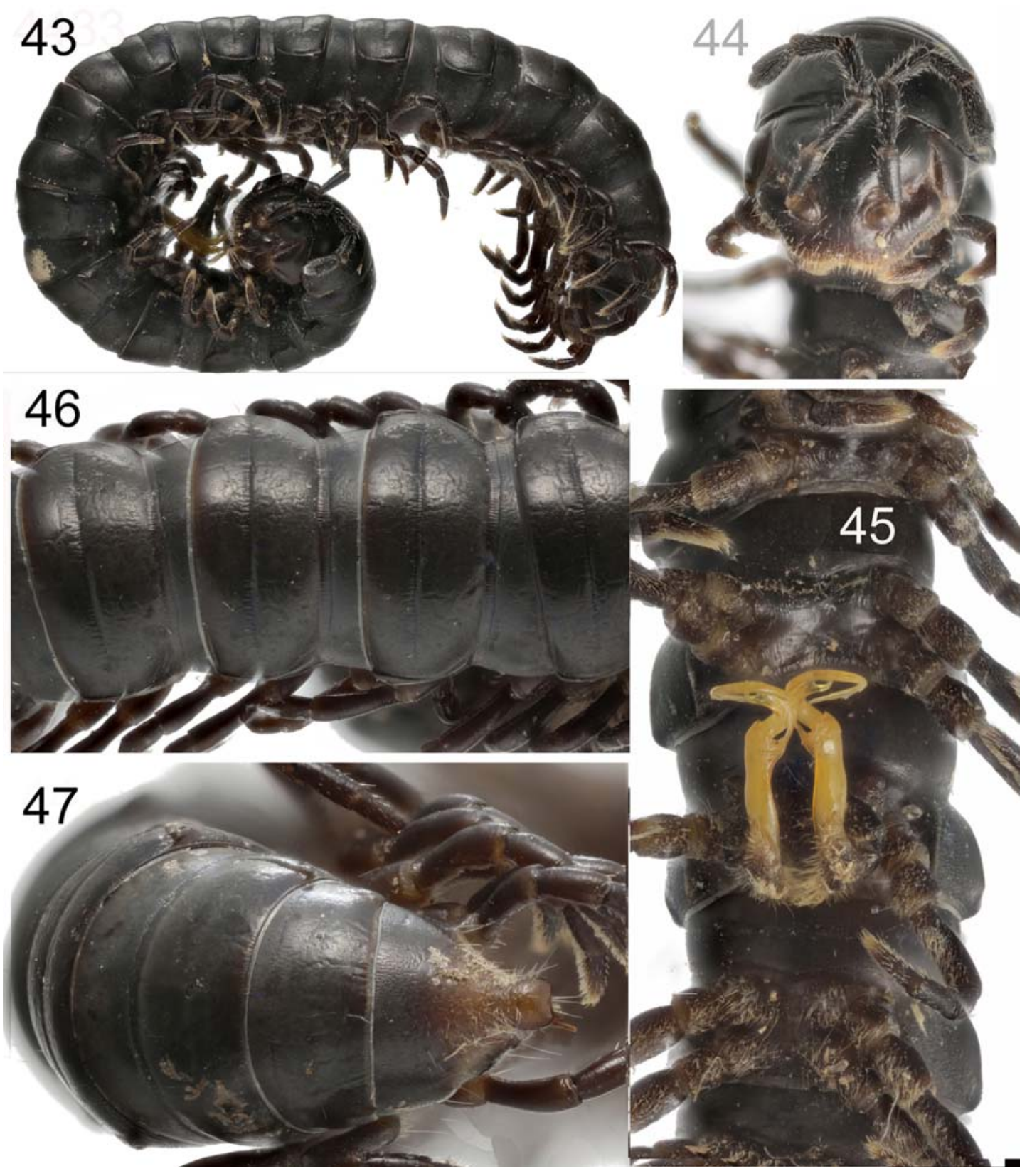

Figs 43-47. Hedinomorpha flavobulbus Golovatch, 2019, $0^{7}$ topotype: 43 - habitus, lateral view; 44 - anterior part of body, ventral view; 45 - segments 5-8 and gonopods in situ, ventral view; 46 - midbody segments, dorsal view; 47 — posterior part of body, dorsal view. Pictures by K. Makarov, not taken to scale.

Рис. 43-47. Hedinomorpha flavobulbus Golovatch, 2019, топотип О': 43 - общий вид, сбоку; 44 - передняя часть тела, снизу; 45 - сегменты 5-8 и гоноподы на месте, снизу; 46 - среднетуловищные сегменты, сверху; 47 - задняя часть тела, сверху. Фотографии К.В. Макарова, сняты без масштаба.

variations in the coloration of the bulbous epiproct (light brown to brown) and the shape of process $\mathbf{k}$ on the solenophore (a more or less narrow and always curved ribbon or lobe).

\section{Parasundanina gen.n.}

DIAGNOSIS. A genus of the tribe Sundaninini, Paradoxosomatidae, differing from all nine presently known genera of the tribe except Arthrogonopus Jeekel, 1963 by the distinct, lateral, distofemoral sulcus on the gonopodal telopodite that delimits a postfemoral part, from Arthrogonopus, with six species endemic to Borneo, all keyed [Golovatch, 1996], by the presence of a distinct, ventral, postfemoral process, coupled with both laminae of the solenophore, lateralis and medialis, being rather evident and partly sheathing a long and filiform solenomere.

Type species: Parasundanina faillei sp.n.

Other species included: P. medialis (Nguyen, 2010), comb.n. ex Sundanina Attems, 1914. 


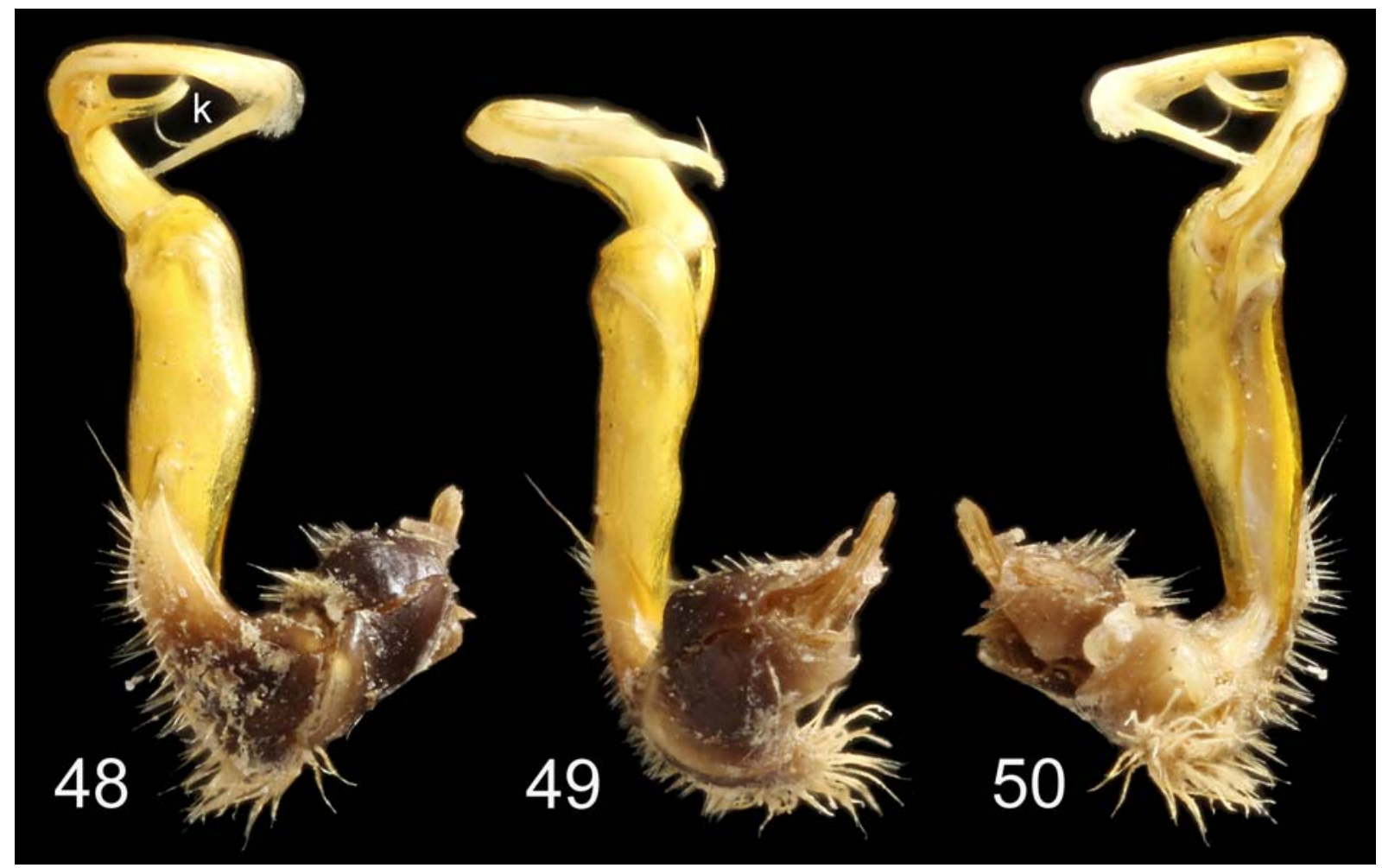

Figs 48-50. Left gonopod of Hedinomorpha flavobulbus Golovatch, 2019, ơ typotype, lateral, dorsal and mesal views, respectively. Pictures by K. Makarov, not taken to scale. Designation explained in text.

Figs 48-50. Левый гонопод Hedinomorpha flavobulbus Golovatch, 2019, топотип О7, соответственно сбоку, сверху и изнутри. Фотографии К.В. Макарова, сняты без масштаба. Объяснение обозначения даны в тексте.

REMARKS. The tribe Sundaninini is presently known to comprise 45 species in nine genera [Golovatch, 1996, 2016; Nguyen, 2010], most of which are endemic to the Sunda region (Borneo, Singapore, Sumatra, Java and some other islands of Indonesia). Only some four species from three genera of Sundaninini have heretofore been recorded from Indochina generally and from Vietnam in particular [Nguyen, 2010].

\section{Parasundanina faillei sp.n. Figs 51-60.}

HOLOTYPE $\sigma^{7}$ (IEBR), Vietnam, Cao Bang Prov., Trà Linh District, Quoc Toan, Lung Riec 1 Cave, N22 $2^{\circ} 5^{\prime} 08.3^{\prime \prime}$, E106 $20^{\prime}$ 02.7", 698 m,18.X.2018, leg. A. Faille, V.T. Tu, P.V. Phu.

PARATYPES: $1 \sigma^{7}$ (MNHN JA 140), same place, together with holotype; $2 \sigma^{7} \sigma^{7}, 1$ \% 2 juv. (MNHN JA 140), same locality, Kyrang Cave, N22 $46^{\prime} 06.8^{\prime \prime}$, E106 $17^{\prime} 31.2^{\prime \prime}$, ca. $630 \mathrm{~m}$ a.s.1., 16.X.

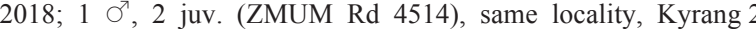
Cave, N22 $45^{\prime} 57.2^{\prime \prime}$, E106 $17^{\prime} 31.8^{\prime \prime}$, ca. $645 \mathrm{~m}$ a.s.1., 16.X.2018; $1 \mathrm{O}^{\top}$ (IEBR), same locality, Kyrang 3 Cave, N22 $2^{\circ} 45^{\prime} 57.4^{\prime \prime}$, E106 $17^{\prime} 35.9^{\prime \prime}$, ca. $655 \mathrm{~m}$ a.s.1, 16.X.2018; $1 \mathrm{O}^{7}, 1$ \% 4 juv. (ZMUM Rd 4515), Cao Bang Prov., Ha Lang District, Hang Doi, Đong Loan Cave, N22 $44^{\prime} 47.7^{\prime \prime}$, E106 $44^{\prime} 35.9^{\prime \prime}$, ca. 385 m a.s.1., 20.X.2018, all leg. A. Faille, V.T. Tu, P.V. Phu.

NAME. Honours Arnaud Faille, the main collector and my good friend.

DIAGNOSIS. Differs from P. medialis (Nguyen, 2010), the only congener known to date, by the lighter coloration (Figs 51-57) (vs. mainly castaneous brown), the poorlydeveloped paraterga with thin calluses and no lateral indentations (Figs 51-56) (vs. well-developed paraterga with con- siderably thicker calluses and small, but evident lateral indentations), the transverse metatergal sulcus starting with segment 5 (vs. with segment 2), the legs much longer, $O^{7}$ ones 2.2-2.3 (vs. 1.5) times as long as midbody height, whereas the gonopod (Figs 54, 57, 59, 60) shows a notably shorter and stouter femorite ( $v s$. longer and more slender), a shorter finger-shaped postfemoral process $\mathbf{p}$ curved mesad apically ( $v s$. much longer, spiniform and erect), a particularly strongly developed and finger-shaped lamina medialis (Im) with a characteristic, midway, ventral lobe and a broadly rounded tip ( $v s$. both lamina medialis and lamina lateralis subequal in length and shape, but the former bifid and supplied with a strong distodorsal spine) [Nguyen, 2010].

DESCRIPTION. Length of holotype ca. $35 \mathrm{~mm}$, width of midbody pro- and metazonae 2.6 and $3.3 \mathrm{~mm}$, respectively. Length of adult paratypes ca. 35-39 $\left(\mathrm{O}^{7}\right)$ or $36-40 \mathrm{~mm}$ ( + ), width of midbody pro- and metazonae $2.6-2.9$ and 3.3$3.9 \mathrm{~mm}\left(\mathrm{O}^{7}\right)$ or $2.8-3.0$ and $3.5-4.0 \mathrm{~mm}(+)$, respectively. Coloration in alcohol uniformly light grey-brown to greybrown, only tip of antennomere 6 and entire antennomere 7 sometimes contrasting blackish brown; legs and venter sometimes light yellow (Figs 51-56).

Clypeolabral region rather densely setose, vertigial one bare or nearly so; epicranial suture fine, but distinct (Fig. 54). Antennae long and slender, only slightly clavate (Figs $53,54)$, extending behind metatergum $3\left(\mathrm{O}^{7}\right)$ or $2(+)$ when stretched dorsally. In length, antennomere $2=3=4=5=6>>1=7$. Interantennal isthmus ca. 0.8-0.9 times as wide as diameter of antennal socket (Fig. 54). Tegument generally smooth and shining, only in places finely rugulose, below paraterga 


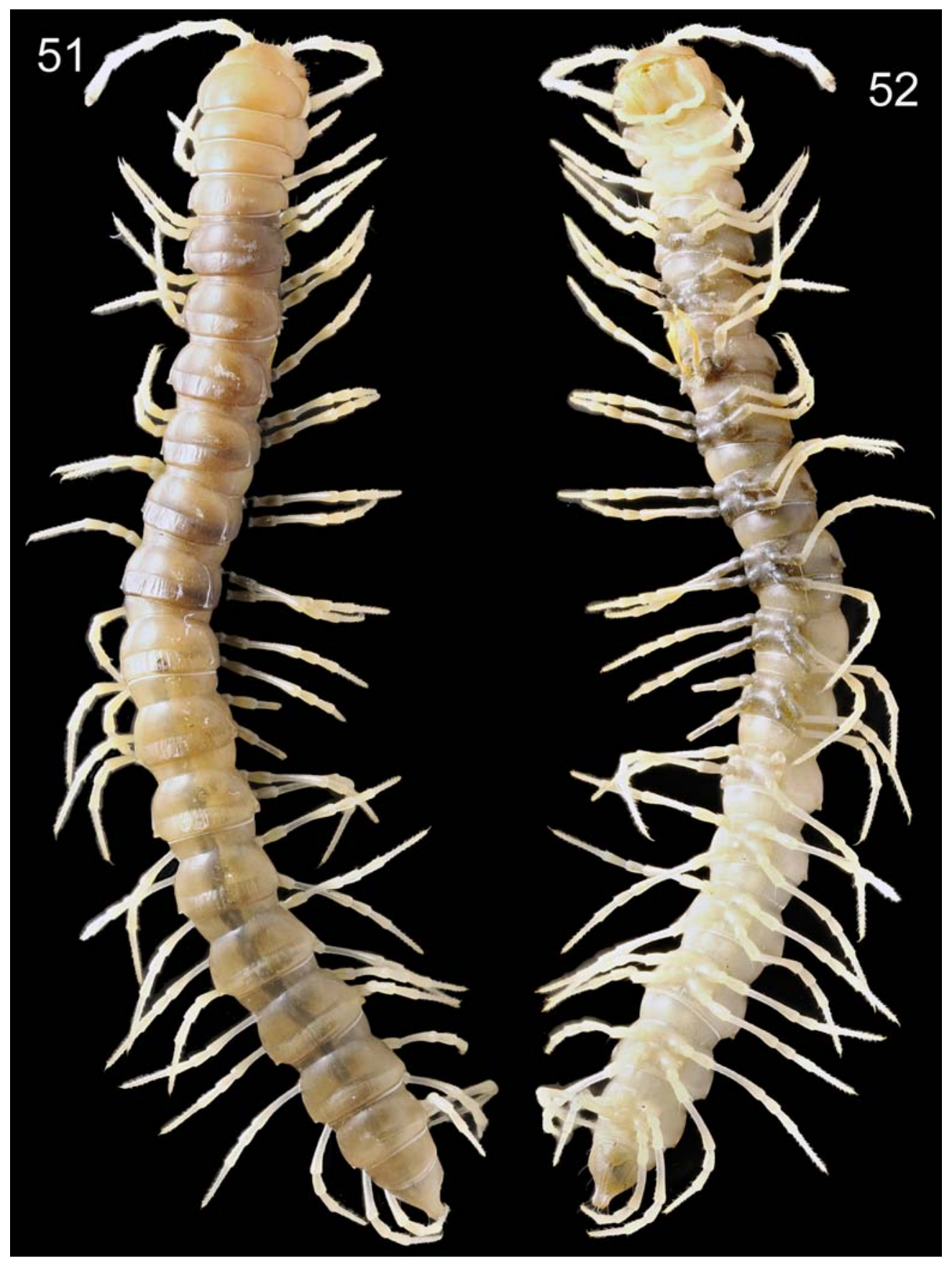

Figs 51-52. Habitus of Parasundanina faillei sp.n., Oج paratype from Kyrang Cave, dorsal and ventral views, respectively. Pictures by K. Makarov, not taken to scale.

Рис. 51-52. Общий вид Parasundanina faillei sp.n., паратип О7 из пещеры Kyrang, соответственно сверху и снизу. Фотографии К.В. Макарова, сняты без масштаба.

finely microgranulate. In width, head $<$ collum $<$ segment 3 $=4<2<5-16$; body gradually tapering thereafter (Figs 51 , $52,56)$. Paraterga poorly-developed, set at about upper $1 / 2$ $1 / 3$ of midbody height; calluses thin, arcuate, with $1-2$ barely visible points (insertion places of setae?) at lateral margin, in lateral view only a little thicker on pore-bearing segments than on poreless ones due to ozopores, delimited by a sulcus only dorsally; paraterga on collum broadly and regularly rounded, declined ventrolaterad like a very convex dorsum; paraterga 2 set especially low, a little drawn into well-rounded lappets both forward and caudad; caudal corners of all paraterga behind $2^{\text {nd }}$ angular, small, dentiform, rather narrowly rounded, never drawn behind caudal tergal margin (Figs 51-56). Ozopores small, lateral, invisible in dorsal view, lying inside an elongate groove at about caudal $1 / 3-1 / 4$ of paraterga. Tergal setae almost fully abraded, ca. $1 / 3$ as long as metatergum, setation pattern untraceable. Limbus entire. Stricture between pro- and metazonae deep 

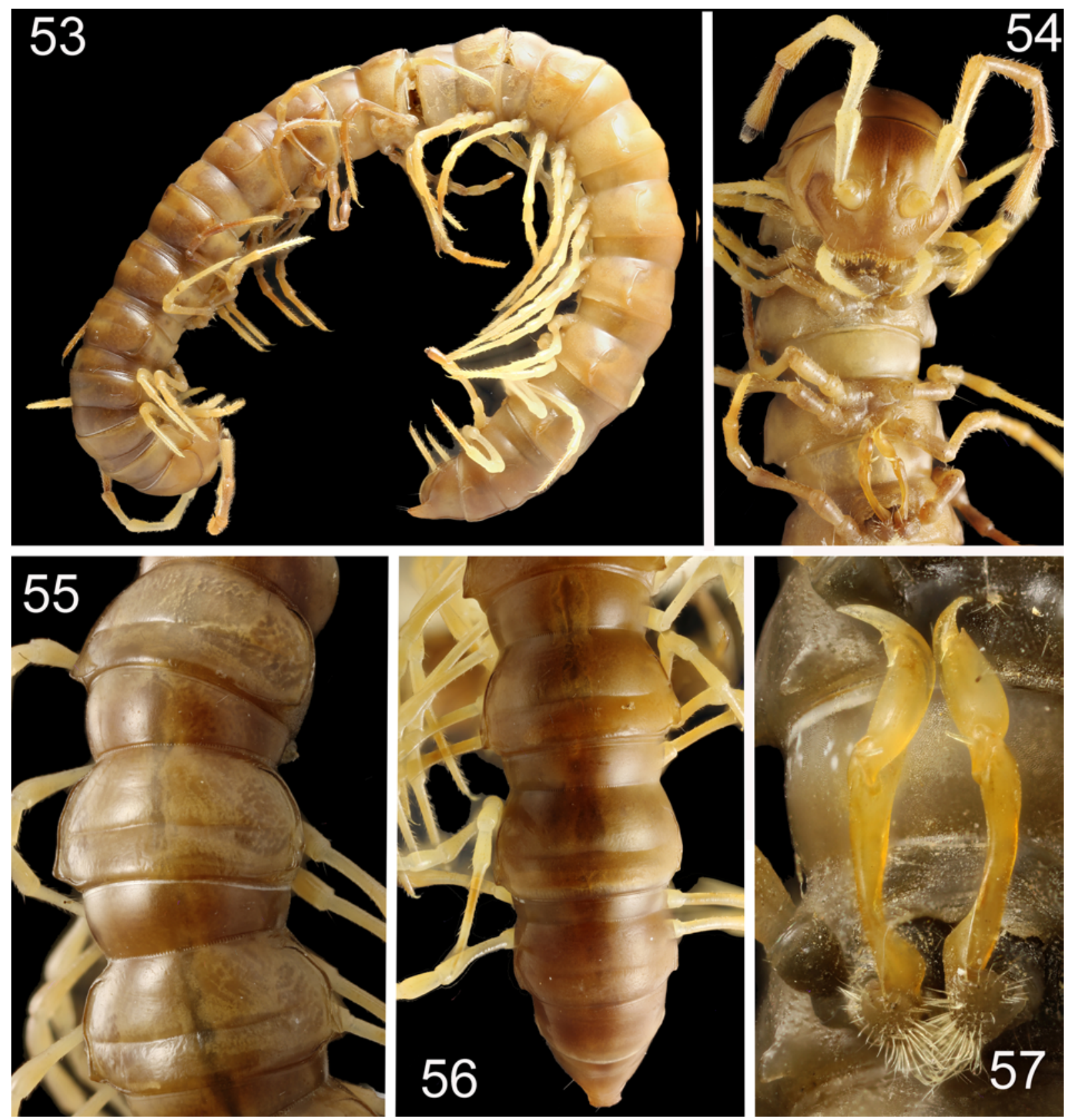

Figs 53-57. Parasundanina faillei sp.n., $0^{7}$ paratype from Lung Riec 1 Cave: 53 - habitus, lateral view; 54 - anterior part of body, ventral view; 55 - midbody segments, dorsal view; 56 - posterior part of body, dorsal view; 57 - gonopods in situ, ventral view. Pictures by K. Makarov, not taken to scale.

Pис. 53-57. Parasundanina faillei sp.n., паратип О7 из пещеры Lung Riec 1: 53 - общий вид, сбоку; 54 - передняя часть тела, снизу; 55 - среднетуловищные сегменты, сверху; 56 - задняя часть тела, сверху; 57 - гоноподы на месте, снизу. Фотографии К.В. Макарова, сняты без масштаба.

and narrow, clearly striate at bottom. Transverse metatergal sulci shallow, simple, slightly arched medially, almost smooth at bottom, almost reaching the bases of paraterga, present on segments 5-18. Axial line missing. Pleurosternal carinae small, but evident, rounded ridges, each with a caudal tooth (Fig. 54), these present on segments 2-8, increasingly reduced towards telson, especially so in + . Epiproct (Fig. 56) long, conical, tip slightly concave, lateral pre-apical papillae small. Hypoproct (Fig. 58) roundly subtriangular, caudal margin with $1+1$ setae borne on very small knobs.
Sterna sparsely setose, cross-impressions shallow, without modifications except for an evident, but low, medially emarginate, setigerous lobe between $\sigma^{7}$ coxae 4 (Fig. 54). No tubercles near gonopod aperture. Legs very long and slender (Figs 51-56), $\sigma^{7}$ ones slightly incrassate compared to + , midbody legs ca. $2.2-2.3\left(\sigma^{7}\right)$ or 1.6-1.7 ( $(+)$ times as long as body height, setose, neither adenostyles nor laterally swollen prefemora, nor ventral brushes.

Gonopods (Figs 54, 57, 59, 60) relatively simple, in situ held parallel to each other, with tips directed laterad. Coxite 

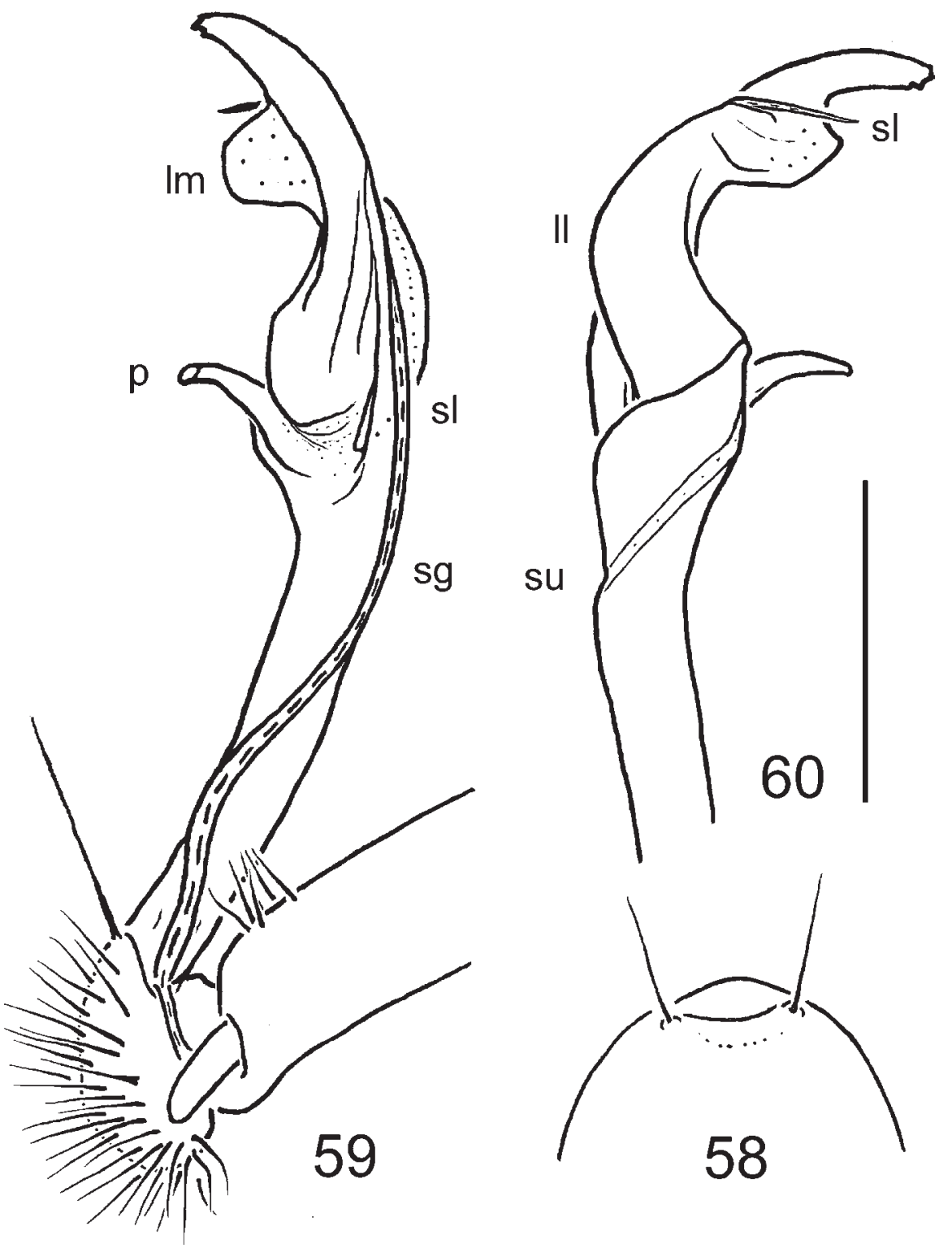

Figs 58-60. Parasundanina faillei sp.n., Ơ paratype from Lung Riec 1 Cave: 58 - hypoproct, ventral view; 59-60 — right gonopod, mesal and lateral views, respectively. Scale bar: $0.5 \mathrm{~mm}$. Designations explained in text.

Рис. 58-60. Parasundanina faillei sp.n., паратип О7 из пещеры Lung Riec 1: 58 - гипопрокт, снизу; 59-60 — правый гонопод, соответственно изнутри и сбоку. Масштаб: 0,5 мм. Объяснения обозначений даны в тексте.

subcylindrical, almost as long as femorite, setose distoventrally; cannula as usual, a small, curved, hollow tube. Prefemoral (= densely setose) part ca. $1 / 3$ and ca. $1 / 5$ as long as femorite and acropodite, respectively. Seminal groove (sg) running along mesal face of femorite, moving onto a long, flagelliform, free solenomere (sl) opposite a simple, ventral, apically mesad directed, finger-shaped prong (p), the latter postfemoral in position because of a distinct, oblique, lateral, distofemoral sulcus (su); sl squeezed between and distally sheathed by a smaller lamina lateralis (II) and a particularly strongly developed lamina medialis (Im) of solenophore, both laminae directed laterad, Im bearing a squarish ventral lobe at midway and a prominent, finger-shaped, rounded, gently curved, apically faintly microspiculate top; only tip of sl clearly exposed.
REMARKS. Among the four Sundaninini hitherto known from Vietnam, P. medialis (Nguyen, 2010), described from the Than Hoa and Ninh Binh provinces, northern Vietnam [Nguyen, 2010], is the sole species that shows all characters of Parasundanina gen.n., in particular a gonopostfemoral lateral sulcus, a ventral postfemoral process, and a strong solenophore with relatively well developed laminae medialis and lateralis that partly sheathe a long and flagelliform solenomere, the latter's tip being exposed on the lateral side. Hence the new combination: Parasundanina medialis (Nguyen, 2010), comb.n. ex Sundanina Attems, 1914.

The new species, $P$. faillei sp.n., comes from several caves, all located in the same province, district and commune in northern Vietnam, and it shows several traits of troglomophism, such as a faintly pigmented body and very 


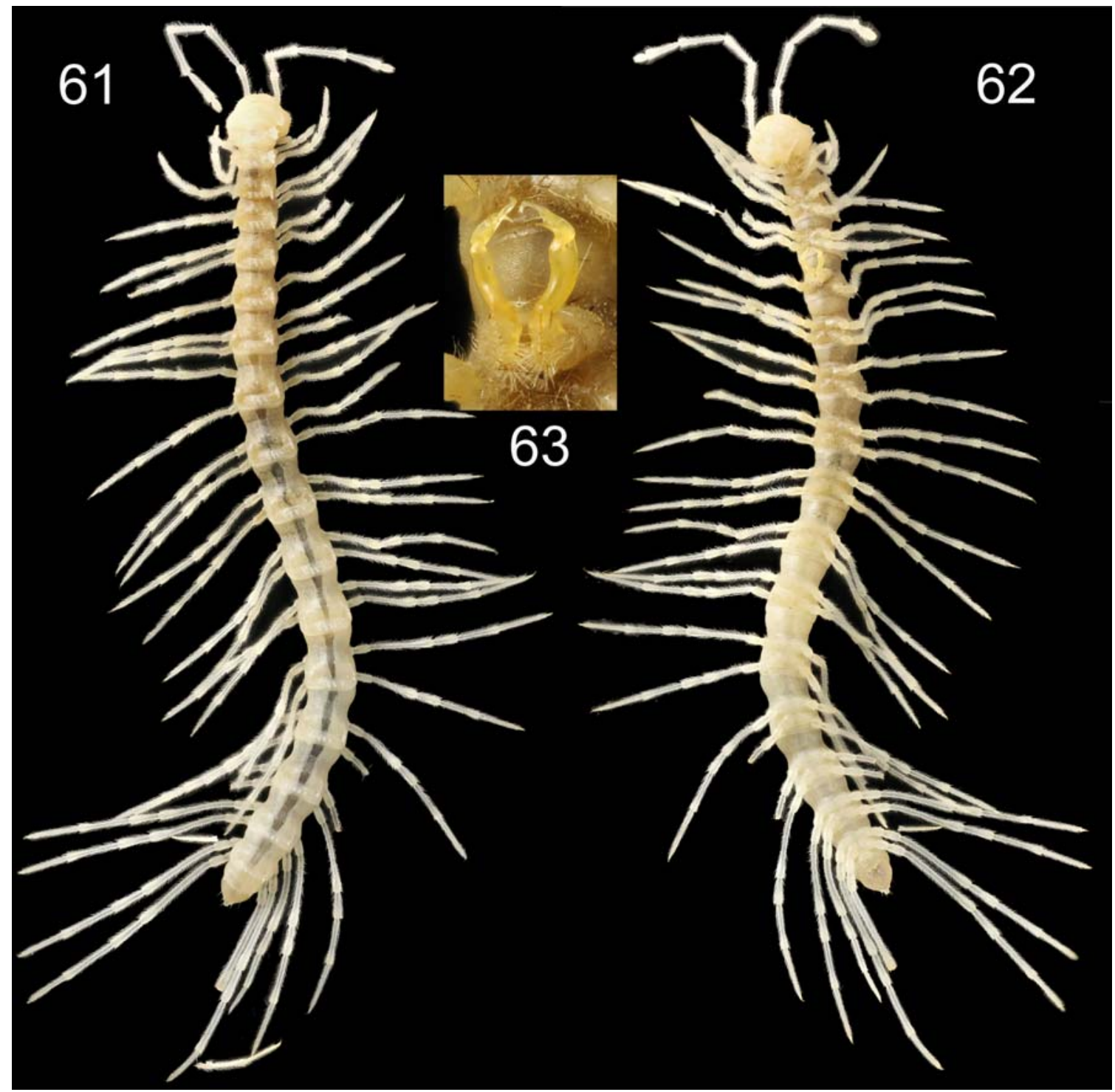

Figs 61-63. Hylomus srisonchaii sp.n., $0^{7}$ paratype from Kyrang Cave: 61-62 — habitus, dorsal and ventral views, respectively; 63 gonopods in situ, ventral view. Pictures by K. Makarov, not taken to scale.

Рис. 61-63. Hylomus srisonchaii sp.n., паратип О7 из пещеры Kyrang: 61-62 - общий вид, соответственно сверху и снизу; $63-$ гоноподы на месте, снизу. Фотографии К.В. Макарова, сняты без масштаба.

long extremities. Whether the species is a troglobite or troglophile, is impossible to say at the moment.

\section{Hylomus srisonchaii sp.n. \\ Figs 61-68.}

HOLOTYPE $\sigma^{7}$ (IEBR), Vietnam, Cao Bang Prov., Trà Linh District, Quoc Toan, Kyrang Cave, N22 $46^{\prime} 06.8^{\prime \prime}$, E106 $17^{\prime} 31.2^{\prime \prime}$, ca. 630 m, 16.X.2018, leg. A. Faille, V.T. Tu, P.V. Phu.

PARATYPES: $2 O^{7} \sigma^{7}, 3$ 우, 3 juv. (IEBR), 3 O $^{7} \sigma^{7}, 2$ 우 (MNHN JA 141), $4 \sigma^{7} \sigma^{7}, 2$ of , several fragments (ZMUM Rd 4516), same place, together with holotype; $20^{7} \sigma^{7}$ (ZMUM Rd 4524), same locality, Kyrang 2 Cave, N22 $45^{\prime} 57.2^{\prime \prime}$, E106 $17^{\prime} 31.8^{\prime \prime}$, ca. $645 \mathrm{~m}$ a.s.1., 16.X.2018; $1 \sigma^{7}$ (IEBR), $1 \mathrm{O}^{7}, 1$ ( 1 (ZMUM Rd 4526). same locality, Kyrang 3 Cave, N22 $45^{\prime} 57.4^{\prime \prime}$, E106 $17^{\prime} 35.9^{\prime \prime}$, ca. $655 \mathrm{~m}$ a.s.l., 16.X.2018; $2 \mathrm{O}^{7} \sigma^{7}, 3$ 우, 1 juv. (ZMUM Rd 4527), Cao Bang Prov., Trà Linh District, Quoc Toan, Lung Riec 1 Cave, $\mathrm{N} 22^{\circ} 45^{\prime} 08.3^{\prime \prime}, \mathrm{E} 106^{\circ} 20^{\prime} 02.7^{\prime \prime}$, ca. 700 m a.s.1., 18.X.2018; $20^{7} \sigma^{7}$,
1 † (ZMUM Rd 4525), Cao Bang Prov., Trà Linh District, Quoc Toan, Lung Riec 1 Cave, N22 $46^{\prime} 12.8^{\prime \prime}$, E106 $17^{\prime} 44.8^{\prime \prime}$, ca. $700 \mathrm{~m}$ a.s.1., 17.X.2018, all leg. A. Faille, V.T. Tu, P.V. Phu.

NAME. Honours Ruttapon Srisonchai, the most prominent specialist in the systematics of "dragon" millipedes, from Bangkok, Thailand.

DIAGNOSIS. Differs from all 34 hitherto known species of Hylomus Cook et Loomis, 1924 [Strisonchai et al., 2018; Liu, Wynne, 2019] by the particularly poorly developed paraterga, coupled with the exceptionally long legs and antennae, the absence of adenostyles, the relatively small lamina lateralis (II) with a rod-shaped apicomesal process, and the well-developed and apically strongly rugged and denticulate lamina medialis $(\mathbf{I m})$ of the solenophore. Due to the small paraterga, this new species vividly resembles both H. laticollis (Liu, Golovatch et Tian, 2016), a cavernicole from southern China, and H. simplex (Golovatch, Vanden- 


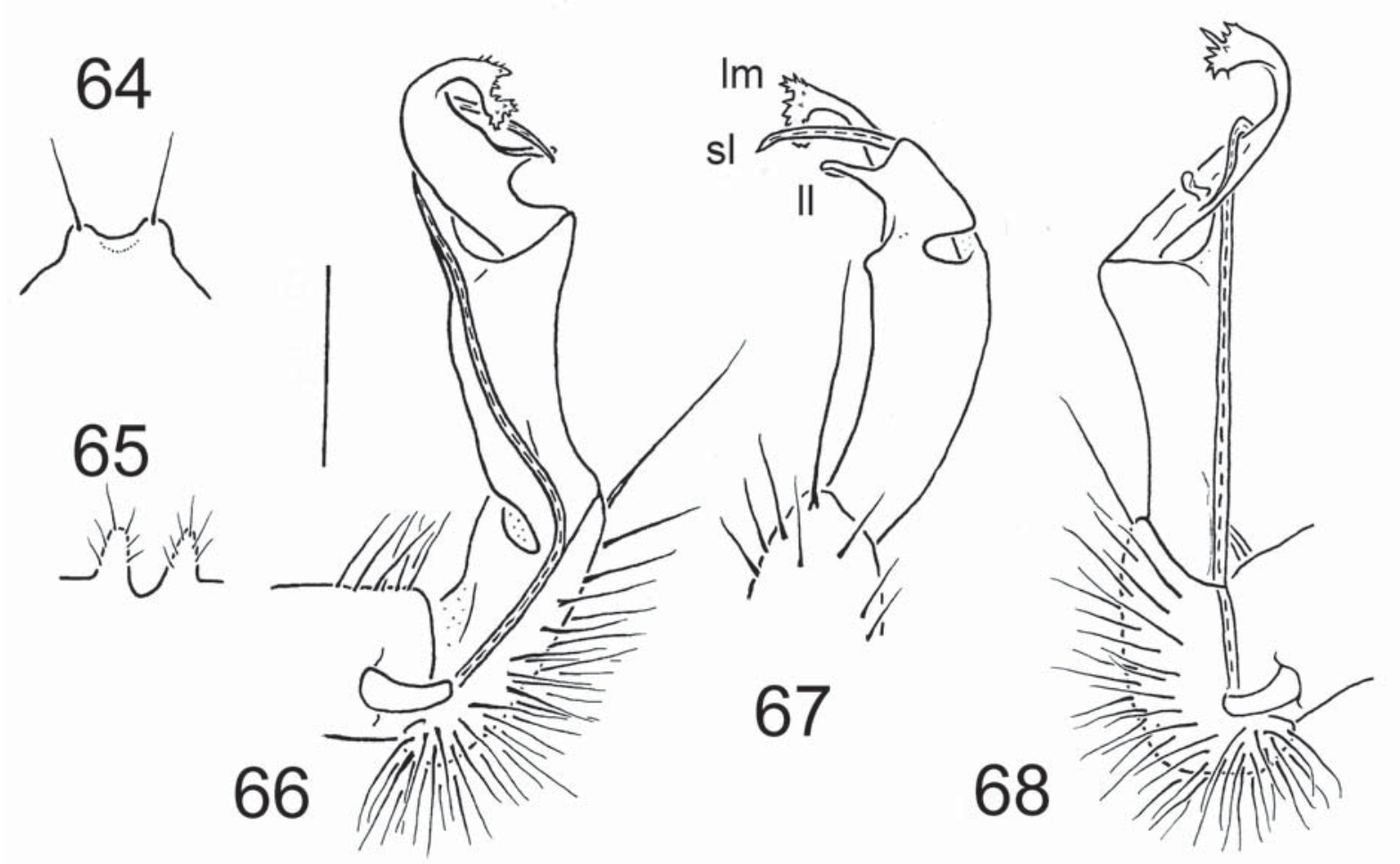

Figs 64-68. Hylomus srisonchaii sp.n., $0^{7}$ paratypes from Kyrang (64-67) and Kyrang 3 (68) caves: 64 - hypoproct, ventral view; 65 sternal structures between coxae 4, caudal view; 66-67 - left gonopod, mesal and ventral views, respectively; 68 - right gonopod, mesal view. Scale bars: $0.4(64,65)$ or $0.2 \mathrm{~mm}(66-68)$. Designations explained in text.

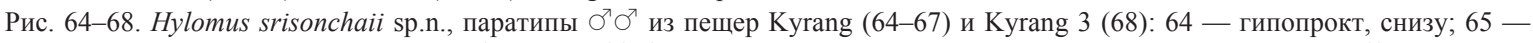
стернальные структуры между тазиками 4, сзади; 66-67 - левый гонопод, соответственно изнутри и снизу; 68 - правый гонопод, изнутри. Масштаб: $0,4(64,65)$ и 0,2 мм (66-68). Объяснения обозначений даны в тексте.

Spiegel et Semenyuk, 2016), a cave-dweller from Laos [Liu et al., 2016; Golovatch et al., 2016], but from the former species it differs readily, among other things, including the gonopodal conformation, by the narrower collum and from the latter species by the granular tegument of the metaterga.

DESCRIPTION. Length of holotype ca. $25 \mathrm{~mm}$, width of midbody pro- and metazonae 1.2 and $1.4 \mathrm{~mm}$, respectively; head $1.6 \mathrm{~mm}$ wide. Length of complete adult paratypes ca. $22-26 \mathrm{~mm}$, width of midbody pro- and metazonae 1.0 1.6 and $1.3-2.0 \mathrm{~mm}\left(\sigma^{\top},+\right.$ ), respectively; head $1.5-2.3 \mathrm{~mm}$ wide. Coloration in alcohol uniformly light grey to pallid (Figs 61, 62), occasionally yellow-brown due to a dirt crust.

Body strongly moniliform. Clypeolabral region densely, vertigial one poorly, setose; epicranial suture fine, but visible (Figs 61, 62). Antennae extremely long and slender, very slightly clavate (Figs 61, 62), extending behind metatergum $6\left(O^{7}\right)$ or $4(9)$ when stretched dorsally. In length, antennomere $3=4=5>2=6>>1=7$. Interantennal isthmus ca. $0.7-0.8$ times as wide as diameter of antennal socket (Fig. 62). Tegument generally dull, microgranulate to granulate; stricture between pro- and metazonae more clearly microgranulate than prozonae. In width, head $>$ collum $>$ segment $2=$ $6-16>5>3=4$; body gradually tapering on segments 17 20 (Figs 61, 62). Collum with $1+1$, sharp, paramedian, setigerous cones in front of caudal margin, 1-2+1-2 similar cones in middle row, and ca. $4+4$ setigerous knobs in anterior row. Paraterga poorly-developed, inconspicuous (especially so for a «dragon» millipede), mostly strongly $\left(\mathrm{O}^{7}\right)$ or slightly (+) upturned, set at about upper $1 / 4$ of midbody height; calluses absent (Figs 61, 62). Paraterga on collum rather small, rounded, slightly declined flaps, each with 3-4, poorly visible, setigerous incisions at lateral margin, caudal corner pointed to almost so, subrectangular and also bearing a seta. Following paraterga increasingly upturned and evident until segment 5 or 6 , thereafter increasingly reduced, each represented by 3-4, sharp, setigerous teeth (until segment 5 or 6), spines (until segment 7 or 8 ) or spinules (thereafter), caudal tooth, spine or spinule always remaining the largest, but slightly drawn past caudal margin only on segments 18 and $19\left(\sigma^{7}\right)$, or paraterga rapidly reduced towards segment 8 , but always clearly visible thereafter $(q$, subadults). Surface between paraterga with two transverse rows of small to evident, setigerous tubercles, crests or cones, typical pattern being $2+2$ smaller knobs in fore row and $2+2$ larger and sharper crests or cones in caudal row (Fig. 61). Ozopores small, inconspicuous, lying ventrally below base of caudal corner. Tergal setae very short, only in anterior row on collum somewhat longer, often abraded, borne on meta- and paratergal tubercles/cones/knobs. Limbus very finely and densely microspiculate. Stricture between pro- and metazonae very broad and shallow. Transverse metatergal sulci or impressions usually evident, arched medially, present on segments 2-18, dividing both transverse rows of setae. Axial line missing. Pleurosternal carinae small, rounded, granular ridges visible on segments $2-4$, almost missing on $5^{\text {th }}\left(\sigma^{7},+\right)$, wanting thereafter. Epiproct 


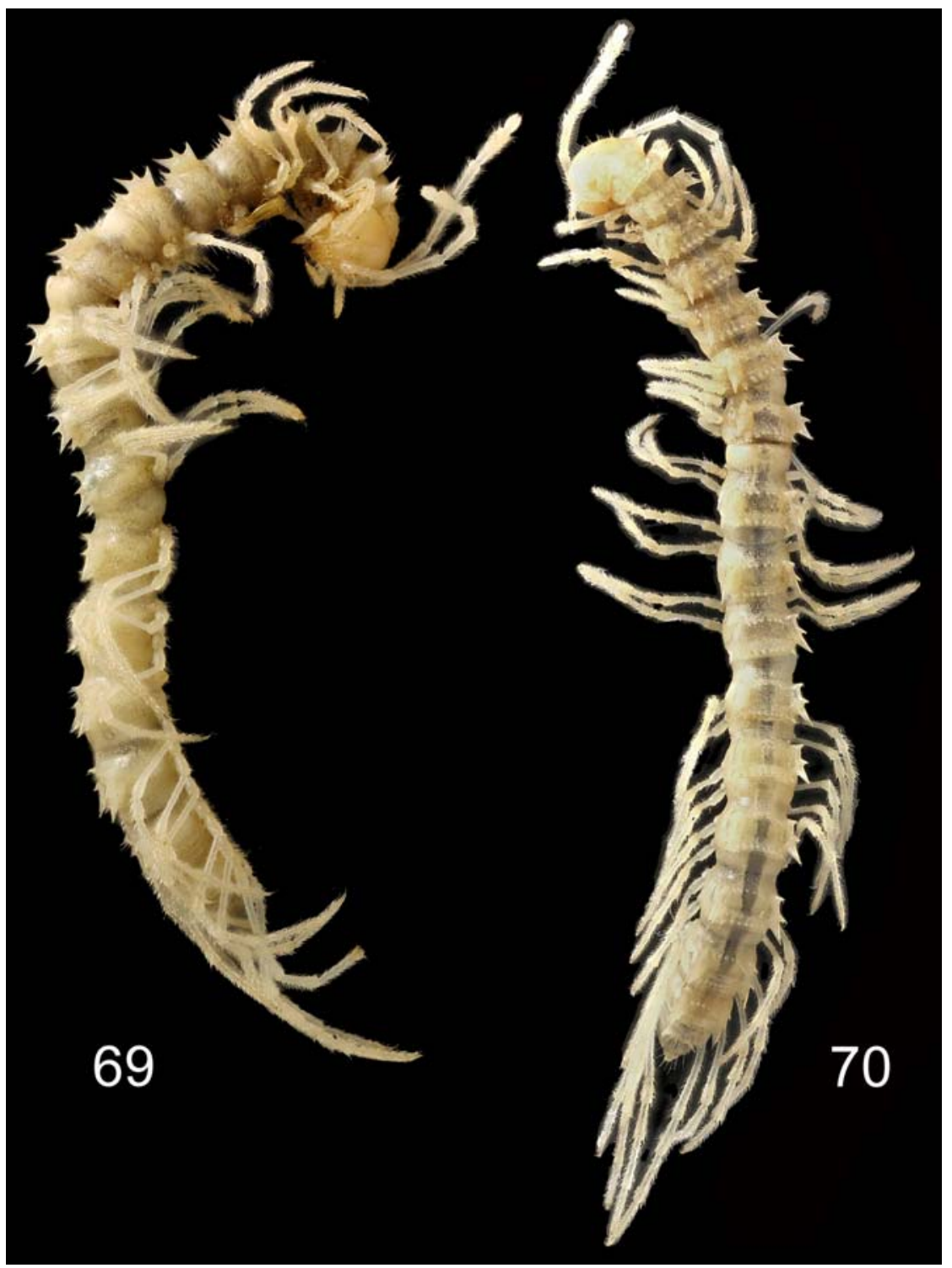

Figs 69-70. Habitus of Hylomus propinquus sp.n., $\bigcirc^{7}$ paratypes, lateral and dorsal views, respectively. Pictures by K. Makarov, not taken to scale.

Рис. 69-70. Общий вид Hylomus propinquus sp.n., паратипы О О7, соответственно сбоку и сверху. Фотографии К.В. Макарова, сняты без масштаба.

(Figs 61, 62) short, roundly quadrate, lateral pre-apical papillae evident. Hypoproct (Fig. 64) subtrapeziform, caudal margin clearly emarginate, with $1+1$ setae borne on distinct knobs.

Sterna moderately setose, cross-impressions very shallow, without modifications except for two evident, paramedian, setose cones between $\sigma^{7}$ coxae 4 (Fig. 65). No tubercles near gonopod aperture (Fig. 63). Legs extremely long and slender (Figs 61, 62), $>4\left(O^{7}\right)$ or $>3(+$, juveniles) times as long as midbody height, densely setose, neither adenostyles nor laterally swollen prefemora, nor ventral brushes.

Gonopods (Figs 63, 66-68) relatively simple, telopodites in situ clearly curved mesad, but tips not crossing each other. Coxite subcylindrical, almost as long as femorite, setose distoventrally; cannula as usual, a small, curved, hollow tube. Prefemoral (= densely setose) part about as long as femorite or solenophore. Seminal groove running along me- sal face of femorite, moving onto a long, flagelliform, free solenomere (sl) level to a distinct, lateral, distofemoral sulcus. Solenophore consisting of two laminae, yet both barely supporting/sheathing the sl: lamina lateralis (II) with a small, but evident, slender, slightly twisted, apicomesal process, about half as long as a slender, distally conspicuously rugged and denticulate lamina medialis (lm); distal half of sl clearly exposed.

REMARK. There is little doubt that this new species is a troglobite.

\section{Hylomus propinquus sp.n. Figs 69-78.}

HOLOTYPE $\sigma^{7}$ (IEBR), Vietnam, Bac kan Prov., Hoang tri commune, Babe (Nà sai village), Cave Tham Phay, N22 $19^{\prime} 11.2^{\prime \prime}$, 

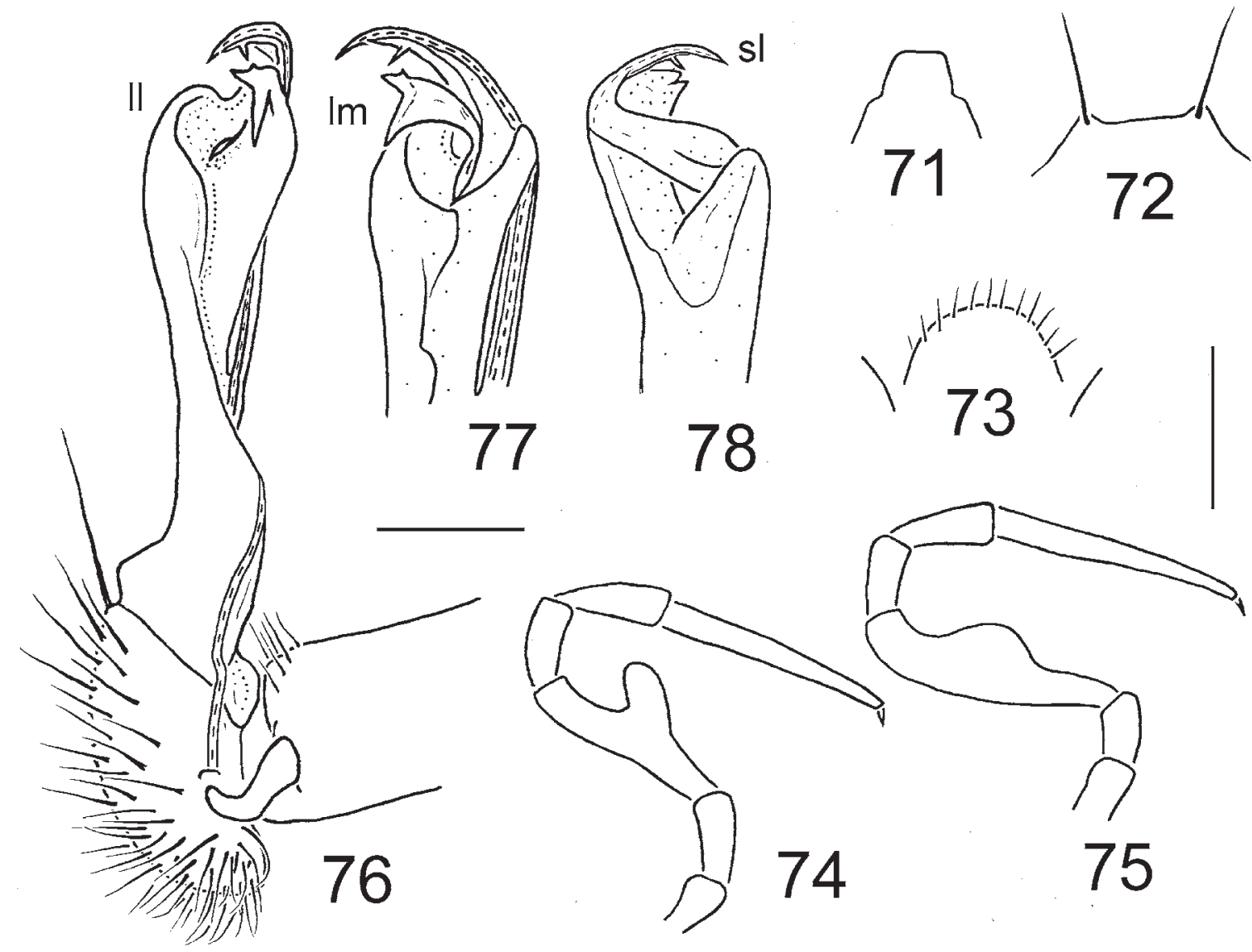

Figs 71-78. Hylomus propinquus sp.n., O' paratypes: 71 - tip of epiproct, dorsal view; 72 - hypoproct, ventral view; 73 - sternal lobe between coxae 4, caudal view; 74 - leg 6, lateral view; 75 - leg 7, lateral view; 76-78 - right gonopod, mesal, subdorsal and ventral views, respectively. Scale bars: $0.4(74,75), 0.2(71-73)$ or $0.2 \mathrm{~mm}(76-78)$. Designations explained in text.

Рис. 71-78. Hylomus propinquus sp.n., паратипы $0^{7} 0^{7}: 71-$ кончик эпипрокта, сверху; 72 - гипопрокт, снизу; $73-$ стернальная пластинка между тазиками 4, сзади; 74 - нога 6, сбоку; 75 - нога 7, сбоку; 76-78 - правый гонопод, соответственно изнутри, почти сверху и снизу. Масштаб: $0,4(74,75), 0,2$ (71-73) и 0,2 мм (76-78). Объяснения обозначений даны в тексте.

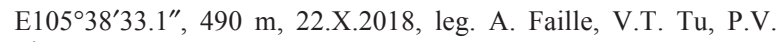
Phu.

PARATYPES: $1 \sigma^{7}, 1$ (IEBR), $1 \bigcirc^{7}, 1$ (MNHN JA 142), 3 $\sigma^{7} \sigma^{7}, 3$ 우, 1 subadult $O^{7}$ (nearly all strongly fragmented) (ZMUM $\mathrm{Rd}$ 4517), same place, together with holotype.

NAME. To emphasize the proximity, both morphological and geographic, to the previous new congener.

DIAGNOSIS. Differs from the apparently most similar $H$. srisonchaii sp.n. (see above), both morphologically and geographically, by the slightly smaller size, the considerably shorter extremities, a peculiar metatergal tuberculation pattern (typically $3(4)+3(4)$ and $3(4)+3(4)$ ), the somewhat more strongly developed paraterga, the modified $\sigma^{7}$ femora 6 and 7 , and the considerably more complex lamina medialis and more simple lamina lateralis of the solenophore etc. (cf. Figs 61-68 and 69-78). Morphologically, both new congeners seem to be particularly similar because they share relatively poorly developed and tridentate postcollum paraterga, several traits of troglomorphism (unpigmented teguments and remarkably long extremities), and the long, flagelliform, apically free solenomere that is barely supported/sheathed by the solenophore.

DESCRIPTION. Length of holotype ca. $17 \mathrm{~mm}$, width of midbody pro- and metazonae 1.0 and $1.6 \mathrm{~mm}$, respective- ly; head $1.8 \mathrm{~mm}$ wide. Length of complete adult paratypes ca. 16-20 mm, width of midbody pro- and metazonae 1.0 1.2 and $1.6-1.7 \mathrm{~mm}\left(\sigma^{7},+\right)$, respectively; head $1.8-2.0 \mathrm{~mm}$ wide. $\sigma^{7} O^{7}$ usually a little smaller and more slender than + . Coloration in alcohol uniformly light yellowish to pallid (Figs 69, 70).

Body strongly moniliform. All characters as in H. srisonchaii sp.n., except as follows.

Antennae very long and slender (Figs 69, 70), but shorter, extending past metatergum $4\left(\mathrm{O}^{7}\right)$ or $3(+)$ when stretched dorsally. Interantennal isthmus ca. 0.6-0.7 times as broad as diamiter of antennal socket. In length, antennomeres 2 $6>>1=7$. Tegument generally dull to poorly-shining. In width, head $>$ segments $5-16>$ collum $>4>2=3$; body gradually tapering on segments 16-20 (Figs 69, 70). Paraterga moderately developed (especially so for a «dragon» millipede), mostly strongly $\left(\mathrm{O}^{7}\right)$ or slightly $(+)$ upturned, set at about upper $1 / 4$ of midbody height; calluses absent (Figs 61, 62). Paraterga on collum distinct, subhorizontal $\left(\mathrm{O}^{7}\right)$ or declined $(+)$ flaps, each with a very evident setigerous incision in front of a sharp, acutangular (ca. $60^{\circ}$ ), also setigerous caudal corner. Following paraterga largely upturned and always evident, especially well so in $\sigma^{7}$, each with three strong, 
sharp, setigerous teeth, caudal tooth always remaining the largest, increasingly inclined caudad, but clearly drawn past caudal margin only on segments 16-19, gradually reduced towards and subhorizontal on segments 18 and 19. Surface between paraterga with two transverse rows of small to evident, setigerous knobs or sharp cones, typical pattern being $3+3$ smaller knobs in fore row and $3+3$ larger sharp cones on segments $2-4(5,6,7)$, to become $3(4)+3(4)$ and $3(4)+3(4)$ on midbody metaterga and, on a few posteriormost metaterga, even to $3(4)+3(4)$ and $4+4$, both rows being separated by a usually distinct transverse sulcus or a weaker impression; lateral cones in caudal row always slightly longer and stronger than intermediate ones (Figs 69, 70). Epiproct (Figs 70,71 ) short, roundly subquadrate, lateral pre-apical papillae small, but evident. Hypoproct (Fig. 72) subtrapeziform, caudally subtruncate, with $1+1$ setae borne on distinct knobs.

Sterna without modifications except for a high, semicircular, setose lobe between $\sigma^{7}$ coxae 4 (Fig. 73). Legs very long and slender (Figs 69,70), $>3\left(\sigma^{7}\right)$ or $>2$ ( 9 , subadult) times as long as midbody height, densely setose, but without ventral brushes; $\sigma^{7}$ femora 6 and 7 conspicuously enlarged (Figs 69, 74. 75).

Gonopods (Figs 76-78) relatively complex. Prefemoral (= densely setose) part about half as long as acropodite. Seminal groove running along a dorsomesal face of femorite, moving onto a long, free, fully exposed, flagelliform solenomere (sl) branching off considerably basal to a distinct, lateral, distofemoral sulcus. Solenophore consisting of two laminae, both subequal in length, but neither sheathing an apically fully independent sl: lamina lateralis (II) a simple rounded lobe, while lamina medialis (Im) deeply split into a long distal spine and a strongly bifid basal ribbon, both slightly spinulate.

REMARK. There is little doubt that this new species is also a troglobite.

Acknowledgements. Special thanks go to Arnaud Faille (Stuttgart, Germany), Dmitri Fedorenko (Moscow, Russia), Yuri Marusik (Magadan, Russia), Dmitry Telnov (Riga, Latvia), Igor Belousov and Ilya Kabak (both St. Petersburg, Russia) not only for kindly allowing me to study the material they collected, but also for their agreement to house it entirely or partly in the ZMUM collection. Arnaud Faille, P.V. Phú and V.T. Tú collected their samples during a biospeleological survey in some caves of northern Vietnam in the framework of the project "Diversity and origin of the hypogean fauna of Vietnam", Associated International Laboratory (LIA) "France, Vietnam, Lao, Cambodia - Tropical Ecology Laboratory" (LIA FVLC-TEL). Kirill Makarov (Moscow, Russia) very skillfully took all pictures. Thanks are likewise due to Kirill Mikhailov and Darya Alkhimova (both ZMUM) who helped me incorporate the ZMUM samples into the collection. Dmitri Fedorenko extends his gratitude to the Russia-Vietnam Joint Tropical Centre which supported his collecting trips to Vietnam.

\section{References}

Chamberlin R.V. 1945. On some diplopods from the Indo-Australian Archipelago // American Museum Novitates. No.1272. P.1-42.
Golovatch S.I. 1995. On several new or poorly-known Oriental Paradoxosomatidae (Diplopoda Polydesmida), II // Arthropoda Selecta. Vol.3. Nos 3-4. P.127-137 (for 1994).

Golovatch S.I. 1996. The millipede family Paradoxosomatidae on Borneo, with contributions to the faunas of some other islands of the Sunda area (Diplopoda: Polydesmida) // Revue suisse de Zoologie. T.103. Fasc.1. P.151-193.

Golovatch S.I. 2014. On several new or poorly-known Oriental Paradoxosomatidae (Diplopoda: Polydesmida), XV // Arthropoda Selecta. Vol.23. No.1. P.1-19.

Golovatch S.I. 2016. On several new or poorly-known Oriental Paradoxosomatidae (Diplopoda: Polydesmida), XX // Arthropoda Selecta. Vol.25. No.3. P.219-240.

Golovatch S.I. 2017. On several new or poorly-known Oriental Paradoxosomatidae (Diplopoda: Polydesmida), XXII // Arthropoda Selecta. Vol.26. No.2. P.87-102.

Golovatch S.I. 2018. On several new or poorly-known Oriental Paradoxosomatidae (Diplopoda: Polydesmida), XXV // Arthropoda Selecta. Vol.27. No.4. P.261-277.

Golovatch S.I. 2019. On several new or poorly-known Oriental Paradoxosomatidae (Diplopoda: Polydesmida), XXVI // Arthropoda Selecta. Vol.28. No.3. P.347-367.

Golovatch S.I., Semenyuk I.I. 2018. On several new or poorlyknown Oriental Paradoxosomatidae (Diplopoda: Polydesmida), XXIV // Arthropoda Selecta. Vol.27. No.3. P.187-200.

Golovatch S.I., Stoev P. 2009. New or poorly-known millipedes (Diplopoda) from Papua New Guinea, $1 / /$ Arthropoda Selecta. Vol.18. Nos 3-4. P.125-130.

Golovatch S.I., VandenSpiegel D., Semenyuk I.I. 2016. On several new or poorly-known Oriental Paradoxosomatidae (Diplopoda: Polydesmida), XXI // Arthropoda Selecta. Vol.25. No.4. P.335-354

Jeekel C.A.W. 1979. A revision of the Sumatran Paradoxosomatidae (Diplopoda, Polydesmida) in the Museo civico di Storia Naturale at Genoa // Bijdragen tot de Dierkunde. Deel 49, No.2. P.163-193.

Likhitrakarn N., Golovatch S.I., Panha S. 2011. Revision of the Southeast Asian millipede genus Orthomorpha Bollman, 1893, with the proposal of a new genus (Diplopoda, Polydesmida, Paradoxosomatidae) // ZooKeys. Vol.131. P.1-161. http:// dx.doi.org/10.3897/zookeys.131.1921

Likhitrakarn N., Golovatch S.I., Panha S. 2016. The millipede genus Tylopus Jeekel, 1968 (Diplopoda, Polydesmida, Paradoxosomatidae), with a key and descriptions of eight new species from Indochina // European Journal of Taxonomy. Vol.195. P.1-47. http://dx.doi.org/10.5852/ejt.2016.195

Liu W.X., Wynne J.J. 2019. Cave millipede diversity with the description of six new species from Guangxi, China // Subterranean Biology 30: 57-94. https://doi.org/10.3897/subtbiol. 30.35559

Liu W.X., Golovatch S.I., Tian M.Y. 2016. Six new species of dragon millipedes, genus Desmoxytes Chamberlin, 1923, mostly from caves in China (Diplopoda, Polydesmida, Paradoxosomatidae) // ZooKeys. Vol.577. P.1-24. http://dx.doi.org/10.3897/ zookeys.577.7825

Nguyen D.A. 2010. The millipede tribe Sundaninini in Vietnam (Diplopoda: Polydesmida: Paradoxosomatidae) // Zootaxa. Vol.2479. P.59-68.

Nguyen D.A. 2012. Tylopus millipedes in Vietnam (Diplopoda: Polydesmida: Paradoxosomatidae: Sulciferini), with descriptions of five new species // Raffles Bulletin of Zoology. Vol.60. No.2. P.278-311.

Strisonchai R., Enghoff H., Likhitrakarn N., Panha S. 2018. A revision of dragon millipedes I: genus Desmoxytes Chamberlin, 1923, with the description of eight new species (Diplopoda, Polydesmida, Paradoxosomatidae) // ZooKeys. Vol.761. P.1-177. https://doi.org/10.3897/zookeys.761.24214

Responsible editor K.G. Mikhailov 